\title{
Exchange of reactive nitrogen compounds: concentrations and fluxes of total ammonium and total nitrate above a spruce canopy
}

\author{
V. Wolff ${ }^{1, *}$, I. Trebs ${ }^{1}$, T. Foken ${ }^{2}$, and F. X. Meixner ${ }^{1,3}$ \\ ${ }^{1}$ Max Planck Institute for Chemistry, Biogeochemistry and Air Chemistry Department, P.O. Box 3060, \\ 55020 Mainz, Germany \\ ${ }^{2}$ University of Bayreuth, Department of Micrometeorology, 95440 Bayreuth, Germany \\ ${ }^{3}$ University of Zimbabwe, Department of Physics, P.O. Box MP 167, Harare, Zimbabwe \\ *now at: Agroscope ART, Air Pollution and Climate Group, 8046 Zürich, Switzerland
}

Received: 4 November 2009 - Published in Biogeosciences Discuss.: 16 November 2009

Revised: 10 May 2010 - Accepted: 18 May 2010 - Published: 25 May 2010

\begin{abstract}
Total ammonium (tot- $\mathrm{NH}_{4}^{+}$) and total nitrate (tot- $\mathrm{NO}_{3}^{-}$) provide chemically conservative quantities in the measurement of surface exchange of reactive nitrogen compounds ammonia $\left(\mathrm{NH}_{3}\right)$, particulate ammonium $\left(\mathrm{NH}_{4}^{+}\right)$, nitric acid $\left(\mathrm{HNO}_{3}\right)$, and particulate nitrate $\left(\mathrm{NO}_{3}^{-}\right)$, using the aerodynamic gradient method. Total fluxes were derived from concentration differences of total ammonium $\left(\mathrm{NH}_{3}\right.$ and $\left.\mathrm{NH}_{4}^{+}\right)$and total nitrate $\left(\mathrm{HNO}_{3}\right.$ and $\left.\mathrm{NO}_{3}^{-}\right)$measured at two levels. Gaseous species and related particulate compounds were measured selectively, simultaneously and continuously above a spruce forest canopy in south-eastern Germany in summer 2007. Measurements were performed using a wetchemical two-point gradient instrument, the GRAEGOR. Median concentrations of $\mathrm{NH}_{3}, \mathrm{HNO}_{3}, \mathrm{NH}_{4}^{+}$, and $\mathrm{NO}_{3}^{-}$were $0.57,0.12,0.76$, and $0.48 \mu \mathrm{g} \mathrm{m}^{-3}$, respectively. Total ammonium and total nitrate fluxes showed large variations depending on meteorological conditions, with concentrations close to zero under humid and cool conditions and higher concentrations under dry conditions. Mean fluxes of total ammonium and total nitrate in September 2007 were directed towards the forest canopy and were $-65.77 \mathrm{ng} \mathrm{m}^{-2} \mathrm{~s}^{-1}$ and $-41.02 \mathrm{ng} \mathrm{m}^{-2} \mathrm{~s}^{-1}$ (in terms of nitrogen), respectively. Their deposition was controlled by aerodynamic resistances only, with very little influence of surface resistances. Including measurements of wet deposition and findings of former studies on occult deposition (fog water interception) at the study site, the total N deposition in September 2007 was estimated to $5.86 \mathrm{~kg} \mathrm{ha}^{-1}$.
\end{abstract}

Correspondence to: V. Wolff (veronika.wolff@art.admin.ch)

\section{Introduction}

Reactive nitrogen $\left(\mathrm{N}_{\mathrm{r}}\right)$ compounds, comprising inorganic reduced forms of $\mathrm{N}$ (e.g., ammonia $\left(\mathrm{NH}_{3}\right)$ and ammonium $\left(\mathrm{NH}_{4}^{+}\right)$), inorganic oxidized forms (e.g., nitrogen oxide $\left(\mathrm{NO}_{\mathrm{x}}\right)$, nitric acid $\left(\mathrm{HNO}_{3}\right)$, nitrous acid (HONO), nitrate $\left(\mathrm{NO}_{3}^{-}\right)$and nitrous oxide $\left.\left(\mathrm{N}_{2} \mathrm{O}\right)\right)$ as well as organic compounds (e.g., urea, amines, proteins, and nucleic acids), play important roles in atmospheric chemistry and in ecosystem functioning.

Atmospheric wet and dry deposition is a major pathway to remove $\mathrm{N}_{\mathrm{r}}$ from the atmosphere, hence a major input path of $\mathrm{N}_{\mathrm{r}}$ into ecosystems. Wet deposition encompasses the processes which transfer airborne species to the Earth's surface in aqueous form, while dry deposition is the transport of gaseous and particulate species towards the surface in the absence of precipitation. A special component of wet deposition, which might be important in specific areas, is the occult deposition through the interception of fog water. Although the hydrological input may not be important in comparison to rain, the concentration of dissolved compounds may be significantly higher, thus being an important pollutant and nutrient input (Eugster, 2008; Klemm and Wrzesinsky, 2007; Zimmermann and Zimmermann, 2002). The relative importance of the different deposition processes for a given chemical compound depends on whether the substance is present in gaseous or particulate form, its solubility in water, the amount of precipitation in the region and the terrain and land surface cover type (Seinfeld and Pandis, 1998; Erisman et al., 2005b; Foken et al., 1995).

Several methods exist to estimate bulk and dry $\mathrm{N}_{\mathrm{r}}$ deposition loads. These are throughfall methods and

Published by Copernicus Publications on behalf of the European Geosciences Union. 
micrometeorological methods to determine exchange fluxes of single $\mathrm{N}_{\mathrm{r}}$ compounds or sums of those. Throughfall, often used in forestry studies (Lovett and Lindberg, 1984; Berger et al., 2008; Hovmand and Andersen, 1995), may be regarded as the sum of wet and dry deposition and canopy exchange, as throughfall is the sum of direct precipitation, wash off of formerly dry deposited material and exchange processes within the canopy (Lovett and Lindberg, 1984). Dry deposition estimates from throughfall measurements are very controversial, particularly for those species that potentially interact with the canopy $\left(\mathrm{NH}_{4}^{+}\right.$and $\mathrm{NO}_{3}^{-}$) (Lovett et al., 1996; Berger et al., 2009), but they are still often used as reasonable estimates (van Breemen and van Dijk, 1988). Micrometeorological methods, like the eddy covariance method have advantages such as the capability to directly measure the dry deposition flux, spatial representativeness and high temporal resolution. They do, however, have high demands to the study site, such as horizontal homogeneity and atmospheric stationarity. Moreover, eddy covariance measurements require fast sensors for the detection of chemical species $(\sim 10 \mathrm{~Hz})$. If such instruments are not available (e.g., for $\mathrm{HNO}_{3}$ ), the aerodynamic gradient method is often applied, based on the flux-gradient-similarity theory (see below). Both, the eddy covariance as well as the aerodynamic gradient method demand high logistical and financial effort as well as sophisticated measurement techniques for the chemical species of interest (cf. Thomas et al., 2009). Since these prerequisites are often not available, dry deposition is frequently modelled using the inferential method, which is based on the "big leaf multiple resistance approach" (Hertel et al., 2006; Andersen and Hovmand, 1999; Wesely and Hicks, 2000). Typically, the concentration of the chemical species is measured at a single level above the surface and the deposition process is described by resistances, i.e., the aerodynamic resistance $\left(R_{\mathrm{a}}\right)$ derived from micrometeorological quantities, the laminar boundary layer resistance $\left(R_{\mathrm{b}}\right)$, dependent on the individual species of interest, and the surface resistance $\left(R_{\mathrm{c}}\right)$ (or its concentration analogue the canopy compensation point $\left(C_{0}\right)$, for example for $\mathrm{NH}_{3}$ (Farquhar et al., 1980)). The surface resistance is often described by several resistances in series and in parallel, e.g. the cuticular, stomata and soil surface resistances. While $R_{\mathrm{a}}$ and $R_{\mathrm{b}}$ can be calculated from measured micrometeorological quantities, surface related parameters like $R_{\mathrm{c}}$ or $C_{0}$ are derived using empirical parameterizations or are deduced from other studies (cf. Nemitz et al., 2004a; Trebs et al., 2006; Sutton et al., 2000). However, parameterisations of the individual resistances are mostly derived for flat homogeneous terrain and low vegetation and may not be adequate for complex sites, like highly structured, hilly, or forested sites (Hertel et al., 2006; Wesely and Hicks, 2000; Andersen and Hovmand, 1999). Additionally, parameterizations of surface related parameters are only valid for certain temperature and humidity ranges, fertilisation state and vegetation types (cf. Farquhar et al., 1980) and may not always be applied for other ecosystems. The dry deposition of particles, such as particulate $\mathrm{NH}_{4}^{+}$and $\mathrm{NO}_{3}^{-}$is typically very different to the dry deposition of gaseous species (Nemitz et al., 2004a). Generally, deposition velocities depend on aerosol particle size and roughness of the underlying surface and they are about one order of magnitude smaller than those of gaseous compounds (Gallagher et al., 1997, 2002).

From all $\mathrm{N}_{\mathrm{r}}$ compounds, $\mathrm{NH}_{3}$ and $\mathrm{HNO}_{3}$ and their particulate counterparts $\mathrm{NH}_{4}^{+}$and $\mathrm{NO}_{3}^{-}$are regarded as in the main contributors to atmospheric $\mathrm{N}_{\mathrm{r}}$ deposition (Andersen and Hovmand, 1999). $\mathrm{NH}_{3}$ is emitted primarily by agricultural activities, such as volatilization from animal waste and synthetic fertilizers, but also from biomass burning, losses from soils, and fossil fuel combustion (Krupa, 2003). It is an important base constituent in the atmosphere, and neutralises acids, such as sulphuric and nitric acid $\left(\mathrm{HNO}_{3}\right)$ and hydrochloric acid, forming ammonium $\left(\mathrm{NH}_{4}^{+}\right)$salts, whose major portion is present in the fine particle fraction (FinlaysonPitts and Pitts, 1999). High concentrations of $\mathrm{NH}_{3}$ are usually found close to sources since it is either effectively dry deposited close to its source and/or rapidly converted to $\mathrm{NH}_{4}^{+}$ (Ferm, 1998). Particulate $\mathrm{NH}_{4}^{+}$is deposited less quickly and may thus be transported over larger distances. $\mathrm{HNO}_{3}$ is produced from the oxidation of nitrogen oxides $\left(\mathrm{NO}_{\mathrm{x}}\right)$, which are emitted primarily by anthropogenic activities, such as fossil fuel burning. Natural sources are biogenic emissions of nitric oxide (NO) from soils and lightning. The polar and very water soluble $\mathrm{HNO}_{3}$ is removed quickly from the atmosphere, either by dry and wet deposition or by gas-to-particle conversion. This leads to comparatively short atmospheric lifetimes of about 1 day (Huebert and Robert, 1985). Particulate $\mathrm{NO}_{3}^{-}$is formed by the reaction of $\mathrm{HNO}_{3}$ with atmospheric base compounds, such as $\mathrm{NH}_{3}$ and also crustal material such as sodium and calcium, and is found in different size ranges of particles, in the accommodation and in the coarse mode (Seinfeld and Pandis, 1998). Particulate $\mathrm{NH}_{4}^{+}$ and $\mathrm{NO}_{3}^{-}$form the majority of the long-range transported $\mathrm{N}_{\mathrm{r}}$ in the atmosphere (Hertel et al., 2006).

$\mathrm{NH}_{3}, \mathrm{HNO}_{3}$ and $\mathrm{NH}_{4} \mathrm{NO}_{3}$ form a thermodynamic equilibrium between the gaseous species $\left(\mathrm{NH}_{3}, \mathrm{HNO}_{3}\right)$ and particulate $\mathrm{NH}_{4} \mathrm{NO}_{3}$ (in solid or in aqueous form), which is a function of temperature $(T)$ and relative humidity (RH) (Mozurkewich, 1993; Stelson and Seinfeld, 1982):

$\mathrm{NH}_{3 \text { (gaseous) }}+\mathrm{HNO}_{3 \text { (gaseous) }} \stackrel{T, \mathrm{RH}}{\longleftrightarrow} \mathrm{NH}_{4} \mathrm{NO}_{3 \text { (solid/aqueous) }}$

Additionally, the equilibrium of Reaction (R1) depends on the chemical composition of aerosol particles, especially on concentrations of those ions that are competing with $\mathrm{NO}_{3}^{-}$ for the $\mathrm{NH}_{4}^{+}$, such as sulphate $\left(\mathrm{SO}_{4}^{2-}\right)$ and chloride $\left(\mathrm{Cl}^{-}\right)$ (Wexler and Seinfeld, 1992).

The application of the flux-gradient-similarity theory (see below) presumes that vertical fluxes of the measured compounds are constant with height within the atmospheric surface layer (Dyer and Hicks, 1970), which implies that they 
are considered chemically non-reactive tracers (e.g., Trebs et al., 2006). Phase changes due to shifts of the thermodynamic equilibrium between gaseous and particulate species (as a result of fluctuations in $T$ and $\mathrm{RH}$ ) may, however, induce a chemical flux divergence of $\mathrm{NH}_{3}, \mathrm{HNO}_{3}, \mathrm{NH}_{4}^{+}$and/or $\mathrm{NO}_{3}^{-}$. Without correcting for these effects, dry deposition estimates derived from gradient measurements may substantially under- or overestimate the actual turbulent flux (Nemitz and Sutton, 2004; Nemitz et al., 2004a). The sum of both phases, total ammonium (tot- $\mathrm{NH}_{4}^{+}$) and total nitrate (tot- $\mathrm{NO}_{3}^{-}$), are, however, conservative quantities in this respect (Kramm and Dlugi, 1994; Brost et al., 1988). While, for the quantification of the $\mathrm{N}_{\mathrm{r}}$ input in an ecosystem like in this study, the partitioning among gas and particulate phase is of minor importance, measurements of exchange fluxes of individual compounds $\left(\mathrm{NH}_{3}, \mathrm{HNO}_{3}, \mathrm{NH}_{4}^{+}\right.$and $\mathrm{NO}_{3}^{-}$) are a prerequisite for investigating near-surface mechanistic processes required for atmospheric chemistry and transport models.

In this paper we will present measurements of concentrations of ammonia $\left(\mathrm{NH}_{3}\right)$, nitric acid $\left(\mathrm{HNO}_{3}\right)$, particulate ammonium $\left(\mathrm{NH}_{4}^{+}\right)$and nitrate $\left(\mathrm{NO}_{3}^{-}\right)$, and their sums total ammonium (tot- $\mathrm{NH}_{4}^{+}$) and total nitrate (tot- $\mathrm{NO}_{3}^{-}$) above a spruce forest canopy in southeast Germany in summer 2007. We focus on flux determinations of the conservative quantities (tot- $\mathrm{NH}_{4}^{+}$and tot- $\mathrm{NO}_{3}^{-}$), thereby avoiding the potential impact of gas-particle interactions and chemical flux divergences. Using measurements of wet deposition and estimations on occult deposition, we estimate a total $\mathrm{N}_{\mathrm{r}}$ deposition rate for September 2007.

\section{Experimental}

\subsection{Weidenbrunnen research site}

The experiment was conducted in summer/autumn 2007 (25 August-3 October) within the framework of the project EGER (ExchanGE processes in mountainous Regions) at the research site "Weidenbrunnen" $\left(50^{\circ} 08^{\prime} \mathrm{N}, 11^{\circ} 52^{\prime} \mathrm{E}\right.$; $774 \mathrm{~m}$ a.s.1.), a Norway spruce forest site located in a mountainous region in south east Germany (Fichtelgebirge). The surrounding mountainous area extends approx. $1000 \mathrm{~km}^{2}$ and is covered mainly with forest, but also some agricultural land, meadows and lakes. Continuous air quality measurements indicate that the site is characterized as a rural site of Central Europe (Klemm and Lange, 1999; Foken, 2003). It is located in the transition zone from maritime to continental climates with annual average temperatures of $5.0^{\circ} \mathrm{C}$ and average annual precipitation sum of $1162.5 \mathrm{~mm}$ (1971-2000; Foken, 2003). The study site is maintained for more than 10 years by the University of Bayreuth and a variety of studies have been conducted there (Falge et al., 2005; Held and Klemm, 2006; Klemm et al., 2006; Rebmann et al., 2005; Thomas and Foken, 2007; Wichura et al., 2004). The stand age of the Norway spruce (Picea abies) was approx. 54 years (according to Alsheimer, 1997), the mean canopy height was estimated to be $23 \mathrm{~m}$ (Staudt, 2007), and the single sided leaf area index during the measurement campaign was approximately 5.3. Measurements were performed on a $31 \mathrm{~m}$ walkup tower. For the Weidenbrunnen site, Thomas and Foken (2007) determined the roughness parameters displacement height $(d)$ and roughness length $\left(z_{0}\right)$ as $14 \mathrm{~m}$ and $2 \mathrm{~m}$, respectively.

\subsection{Aerodynamic gradient method}

The aerodynamic gradient method (AGM) is based on the gradient-flux similarity and derives fluxes from measured vertical concentration differences and micrometeorological exchange parameters (Ammann, 1998; Foken, 2008). The flux, $F$, is calculated as the product of a turbulent diffusion transfer coefficient, expressing mechanically and thermally induced turbulence, and the vertical concentration difference, $\Delta C$.

$$
F=-\underbrace{\frac{u_{*} \cdot \kappa}{\ln \left(\frac{z_{2}}{z_{1}}\right)+\Psi_{H}\left(\frac{z_{2}}{L}\right)-\Psi_{H}\left(\frac{z_{1}}{L}\right)}}_{v_{\mathrm{tr}}} \cdot \Delta C
$$

where $u_{*}$ is the friction velocity $\left(\mathrm{m} \mathrm{s}^{-1}\right), \kappa$ the von Kármán constant (0.4), $\Psi_{H}$ the integrated stability correction function for sensible heat (considered equal to that of trace compounds), and $z / L$ is height $z$ over the Obukhov length $L$, a measure of atmospheric stability. The first term in the product on the right hand site of the equation is often referred to as the transfer velocity, $v_{\text {tr }}\left(\mathrm{m} \mathrm{s}^{-1}\right)$. It represents the inverse resistance of the turbulent transport between the two heights $z_{1}$ and $z_{2}$ (Ammann, 1998). Note here, that we use all measurement heights $z_{1}, z_{2}$, and $z$, as aerodynamic heights above the zero plane displacement height, $d$. Equation (1) is strictly valid only for "smooth" and even surfaces (e.g. pastures, meadows). However, when using this relationship close to a canopy to infer fluxes from measured vertical concentration gradients, corresponding fluxes have been found to be underestimated (Thom et al., 1975; Garratt, 1978; Högström et al., 1989). Nevertheless, the flux-gradient relationship was found to hold within the so-called roughness sublayer (Garratt, 1978, 1992) above forest canopies, introducing a so-called enhancement factor into the left hand term of the right hand side of Eq. (1) (e.g. Simpson et al., 1998). This enhancement factor needs to be considered for both, momentum and scalar exchange individually. The directly measured $u_{*}$ (with eddy covariance) already accounts for the enhancement of momentum flux in comparison to the original AGM method based on wind speed profiles (Garratt, 1992). Investigations of the temperature profile at the study site revealed that the gradient between the used measured levels was not reduced in comparison to the undisturbed gradient (F. Rütz, personal communication, 2010), most probably due to the 
proximity to the canopy top. Therefore, no enhancement factor for scalars was introduced in our calculations.

An underlying assumption of the AGM is that the flux to or away from the reference surface (here: canopy top) is identical to the vertical flux measured at a reference level in some distance above the surface (see above). This assumption may not hold due to chemical reactions occurring within the air layer between the surface and the reference height (Fowler and Duyzer, 1989; Meixner, 1993). For the determination of total ammonium and total nitrate fluxes this is not of relevance, but it does affect flux determination of individual gaseous and/or particulate compounds $\left(\mathrm{NH}_{3}, \mathrm{HNO}_{3}\right.$, $\mathrm{NH}_{4}^{+}, \mathrm{NO}_{3}^{-}$) as phase changes may lead to flux divergence (e.g. Nemitz et al., 2004a; Brost et al., 1988; Huebert et al., 1988). However, as long as the characteristic time scale of chemical transformation is large in comparison to the turbulent timescale, fluxes of compounds that underlie rapid chemical transformation may be determined with sufficient accuracy when treating them as not-reactive (De Arellano and Duynkerke, 1992; Nemitz et al., 2004b). Photochemical reactions involving $\mathrm{NH}_{3}$ and $\mathrm{HNO}_{3}$ are slow compared to turbulence; however, timescales of phase changes within the $\mathrm{NH}_{3}-\mathrm{HNO}_{3}-\mathrm{NH}_{4} \mathrm{NO}_{3}$ triad (see Reaction R1), may be comparable to characteristic times of turbulent transport (Trebs et al., 2006).

\subsection{The GRadient of AErosol and Gases Online Regis- trator (GRAEGOR)}

The GRAEGOR is a wet chemical instrument for semicontinuous two-point gradient measurements of watersoluble reactive trace gas species $\left(\mathrm{NH}_{3}, \mathrm{HNO}_{3}, \mathrm{HONO}, \mathrm{HCl}\right.$, and $\left.\mathrm{SO}_{2}\right)$ and their related particulate compounds $\left(\mathrm{NH}_{4}^{+}\right.$, $\mathrm{NO}_{3}^{-}, \mathrm{Cl}^{-}, \mathrm{SO}_{4}^{2-}$ ) (Thomas et al., 2009). GRAEGOR collects the gas and particulate samples simultaneously at two heights (for EGER: $24.4 \mathrm{~m}$ and $30.9 \mathrm{~m}$ ) using horizontally aligned wet-annular rotating denuders and steam-jet aerosol collectors (SJAC), respectively. Air is simultaneously drawn through GRAEGOR's sample boxes, passing first the wetannular rotating denuders, where water-soluble gases diffuse from a laminar air stream into the sample liquid. In both SJACs, the sample air (now containing only the aerosol particles) is then mixed with water vapour from double-deionized water and the supersaturation causes particles to grow rapidly (within $0.1 \mathrm{~s}$ ) into droplets of at least $2 \mu \mathrm{m}$ diameter. These droplets, containing the dissolved particulate species are then collected in a cyclone (cf. Slanina et al., 2001). The airflow through the two sample boxes is $\sim 14 \mathrm{~L} \mathrm{~min}^{-1}$ (at STP $=0{ }^{\circ} \mathrm{C}$ and $1013.25 \mathrm{hPa}$ ) per box and is kept constant through a critical orifice downstream of the SJAC. The inlets of the sample boxes, directly connected to the wet-annular rotating denuders, consisted of PFA (perflouroalkoxy) Teflon tubing (I.D. $=0.8 \mathrm{~cm}$, length $=20 \mathrm{~cm}$ ), ended upstream in a homemade PFA Teflon rain protection, and were covered by a PFA gauze. Liquid samples (from both denuders and SJACs) are analyzed online using ion chromatography for anions and by flow injection analysis for $\mathrm{NH}_{4}^{+}$. GRAEGOR provides one half-hourly averaged gas and particulate concentrations for each height for each species within each hour (cf. Thomas et al., 2009). The analytical performance of the instrument is continuously checked using an internal bromide standard that is added to each sample. Calibrations of the ion chromatograph using Merck certiPUR ${ }^{\circledR}$ standard solutions were performed twice, 6-7 September and 26 September. The FIA detector was calibrated weekly. The limit of detection (LOD) for the individual species was determined from infield blanks once a week (for details see Wolff et al., 2010). The errors of the air concentrations of $\mathrm{NH}_{3}, \mathrm{HNO}_{3}$, particulate $\mathrm{NH}_{4}^{+}$, and particulate $\mathrm{NO}_{3}^{-}$were calculated according to Trebs et al. (2004) and Thomas et al. (2009) using Gaussian error propagation. The precision of the measured concentration differences $\left(\sigma_{\Delta C} / C\right)$ was investigated by extended sideby-side measurements in the beginning and at the end of the experiment (Wolff et al., 2010).

\subsection{Supporting measurements}

Vertical profiles of meteorological quantities, such as ambient temperature $(T)$, relative humidity $(\mathrm{RH})$, and wind speed were measured at the tower $(31 \mathrm{~m}$ high) at three heights above the canopy (at $z=24.4,26.6$, and $30.9 \mathrm{~m} \mathrm{(} T$, RH, using psychrometers (fine-wire thermocouples, custom build)) and $z=24.3,26.2$ and, $31.2 \mathrm{~m}$ (wind speed, 3 cup anemometer (A100ML, Vector Instruments, UK))). On top of the tower $(z=32 \mathrm{~m})$, an eddy covariance system (Gill R2 sonic anemometer in combination with a LI-COR-7000) measured three-dimensional wind speed, wind direction, friction velocity, stability, latent, sensible heat and $\mathrm{CO}_{2}$ fluxes. Atmospheric visibility using a present weather detector (PWD 11, Vaisala), global irradiance (pyranometer CM14, Kipp \& Zonen B.V.) and wind direction (potentiometric wind vane, Vector Instruments) were also measured on top of the tower at $32 \mathrm{~m}$ height. Aerosol number size distributions were measured at $28 \mathrm{~m}$ height at the tower using a SMPS (Scanning Mobility Particle Sizer, Grimm).

At a nearby clearing (distance to tower $\sim 250 \mathrm{~m}$ ), a wetonly rainwater collector (NSA 181/KHS Eigenbrodt, 2007) was operated. During the field study, samples were collected event-based and stored cool until analysis (Bavarian Environment Agency (LfU), Augsburg, ion chromatography). In September a total of six rain samples were analysed for chloride, nitrite, nitrate, phosphate, sulphate, sodium, ammonium, potassium, magnesium, and calcium. 
(a)

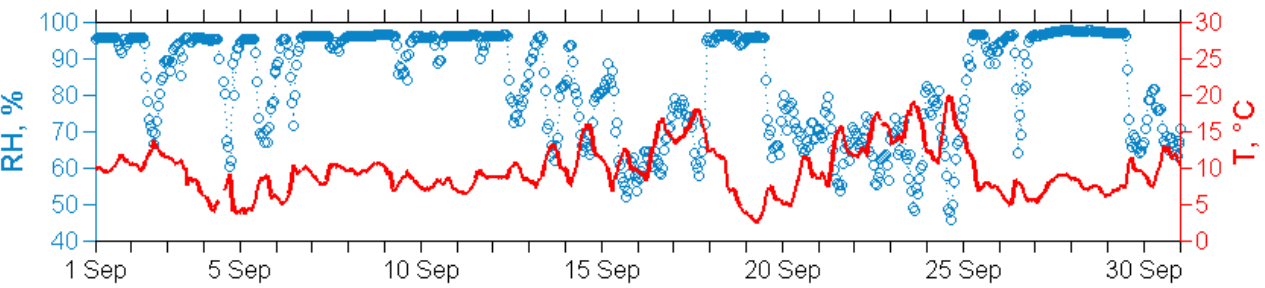

(b) ${ }^{\circ}$
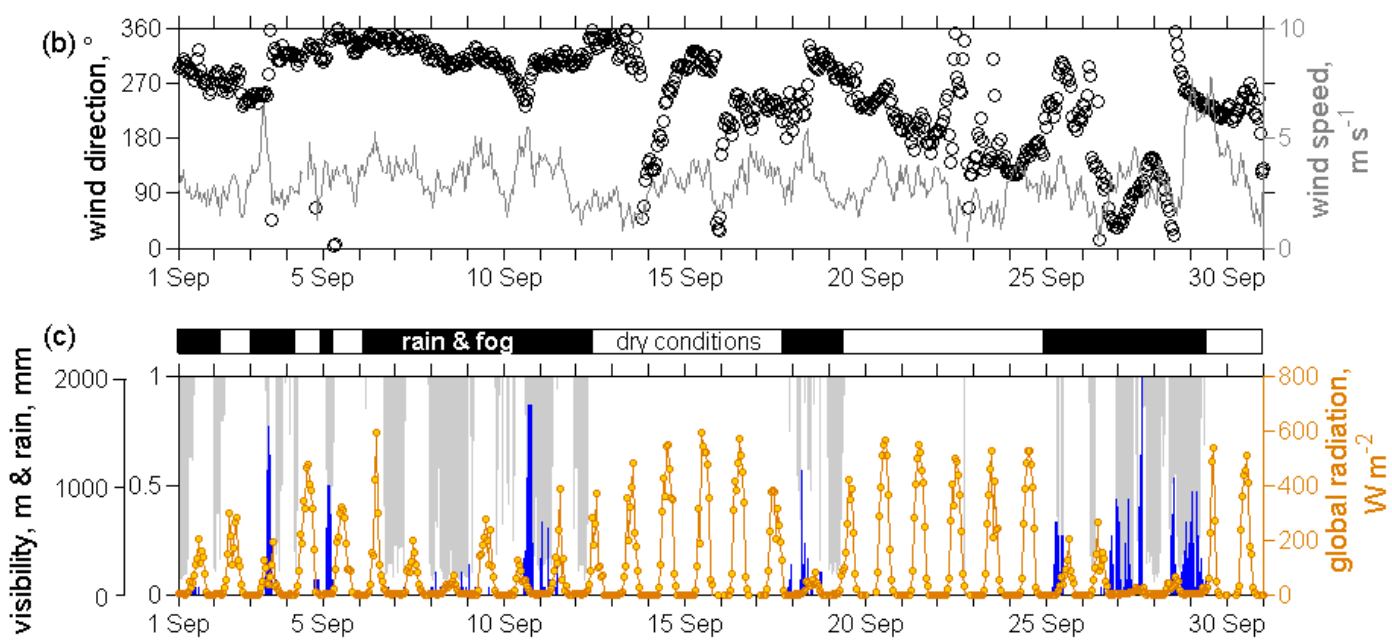

Fig. 1. (a) Air temperature $T$ (red line) and relative humidity RH (blue circles), (b) wind speed (black line) and wind direction (black circles) and (c) rain (blue bars), visibility (grey shaded areas) and global radiation (yellow line) during the EGER experiment (September 2007). Times and dates refer to Central European Time (major ticks indicate midnight).

\section{Results}

\subsection{Meteorological conditions}

Meteorological quantities, such as RH, $T$, wind speed $\left(\mathrm{m} \mathrm{s}^{-1}\right)$, wind direction $\left(^{\circ}\right)$, rain $(\mathrm{mm})$, visibility $(\mathrm{m})$ and global radiation $\left(\mathrm{W} \mathrm{m}^{-2}\right)$ for the month of September in 2007 are summarized in Fig. 1. Two episodes with several consecutive sunny days are in contrast to prevailing humid, foggy conditions with frequent rain and reduced visibility. During fog and rain, the temperature amplitude was reduced and temperatures ranged between below 5 and $15^{\circ} \mathrm{C}$, while RH almost always remained above 70-80\%. During the sunny episodes (12-17 September and 19-24 September) temperatures show a diel variation with increasing temperatures from day to day (up to more than $20^{\circ} \mathrm{C}$ ). During these days, $\mathrm{RH}$ dropped to below $70 \%$ during daytime. The wind speed was generally quite high with a median of $2.8 \mathrm{~m} \mathrm{~s}^{-1}$, ranging between 2 and $4 \mathrm{~m} \mathrm{~s}^{-1}$ (inter quartile range). During the first half of September (foggy conditions), the wind blew frequently from northerly directions, turning towards south westerly directions afterwards.

\subsection{Detection limits, precision and mean concentrations}

To facilitate comparison between the concentrations and fluxes of the different nitrogen containing compounds all numbers are given in terms of nitrogen ${ }^{1}$. In this paper we focus on the measurements made in September 2007. Determined LOD values ( $3 \sigma$-definition) were $0.017 \mu \mathrm{g} \mathrm{m}^{3}$ for $\mathrm{NH}_{3}$ and particulate $\mathrm{NH}_{4}^{+}$, and $0.029 \mu \mathrm{g} \mathrm{m}^{-3}$ for $\mathrm{HNO}_{3}$ and particulate $\mathrm{NO}_{3}^{-}$, respectively (see Wolff et al., 2010). Less than $1 \%$ of the total $\mathrm{NH}_{3}$ concentrations were below the detection limit, less than $2 \%$ of the total particulate $\mathrm{NH}_{4}^{+}$concentrations, but $30 \%$ of the $\mathrm{HNO}_{3}$ concentrations and $8 \%$ of the particulate $\mathrm{NO}_{3}^{-}$concentrations were below corresponding detection limits. Below LOD concentrations were predominantly measured during rainy periods. For tot- $\mathrm{NH}_{4}^{+}$ and for tot- $\mathrm{NO}_{3}^{-}$the precision was found to be $5.3 \%$ and $4.8 \%$, respectively. The median error of the concentration difference $\left(\sigma_{\Delta C} / \Delta C\right)$ was found to be $52.1 \%$ and $37.9 \%$. Measured concentration differences larger than the precision were considered to be significant, while those below the precision were determined to be insignificantly different from zero. For tot- $\mathrm{NH}_{4}^{+}, 55 \%$ of the 443 total measured concentration differences were found to be significant, for tot- $\mathrm{NO}_{3}^{-}$, $77 \%$ of the 373 total concentration differences were significant. From the error of the concentration difference, the flux error is derived in combination with an estimated error

\footnotetext{
${ }^{1}$ All concentrations and fluxes are given in $\mu \mathrm{g} \mathrm{m}^{-3}$ in terms of $\mathrm{N}$. To convert these to $\mu \mathrm{g} \mathrm{m}^{-3}$ they must be multiplied with the ratio of the molar masses, i.e. for $\mathrm{NH}_{3}: 1.216$, for $\mathrm{NH}_{4}^{+}$(and tot- $\mathrm{NH}_{4}^{+}$): 1.288 , for $\mathrm{HNO}_{3}: 4.499$ and $\mathrm{NO}_{3}^{-}$(and tot- $\mathrm{NO}_{3}^{-}$): 4.427 .
} 


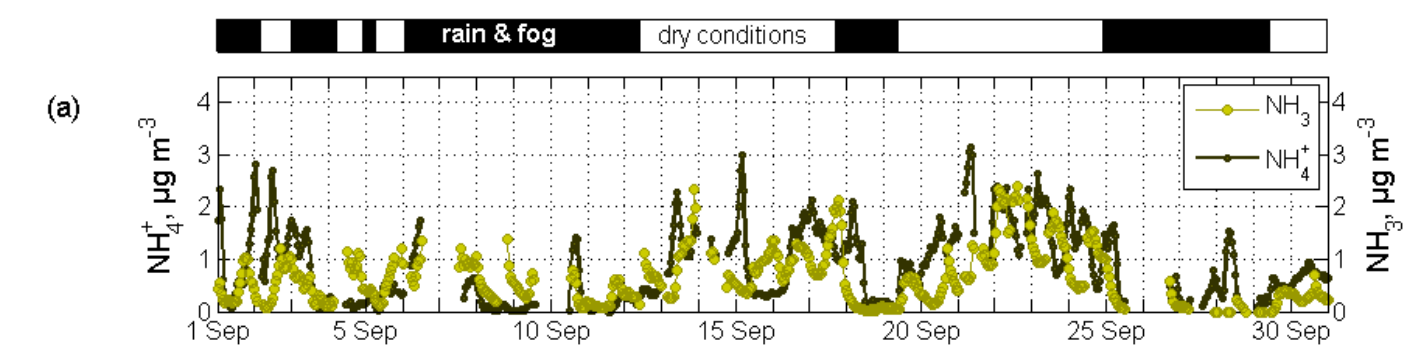

(b)

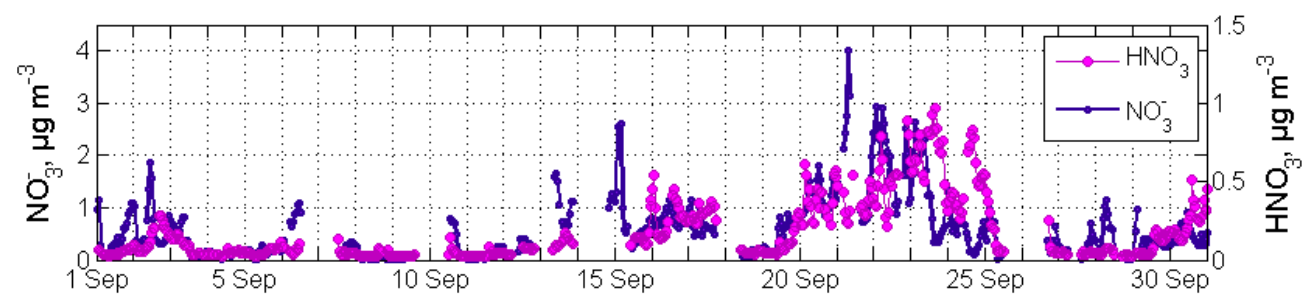

(c)

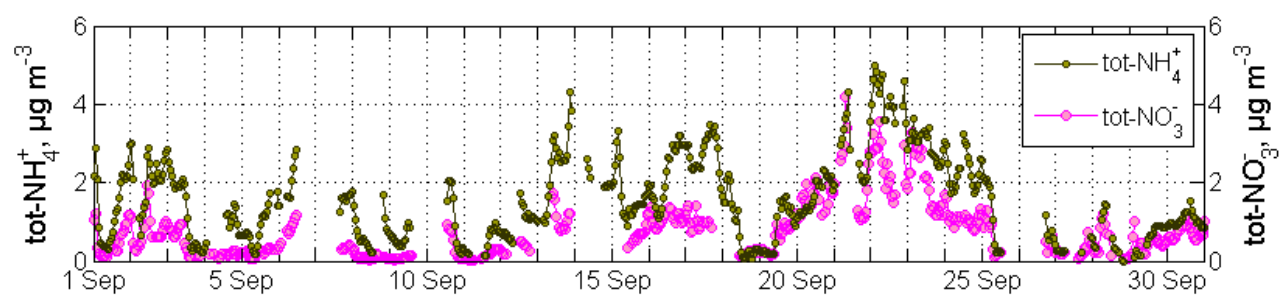

Fig. 2. Diel variations of (a) $\mathrm{NH}_{3}$ and particulate $\mathrm{NH}_{4}^{+}$and (b) $\mathrm{HNO}_{3}$ and particulate $\mathrm{NO}_{3}^{-}$, and (c) tot- $\mathrm{NH}_{4}^{+}$and tot- $\mathrm{NO}_{3}^{-}$(all in $\mu \mathrm{g} \mathrm{m}{ }^{-3}$, in terms of N) measured in September 2007 at $30.9 \mathrm{~m}$ (above ground) at the Weidenbrunnen site. Indicated by the black and white bar are episodes of rain and fog and dry periods, respectively (cf. Fig. 1).

Table 1. : Statistics of $\mathrm{NH}_{3}, \mathrm{NH}_{4}^{+}, \mathrm{HNO}_{3}$, and $\mathrm{NO}_{3}^{-}$concentrations $\left(\mu \mathrm{g} \mathrm{m}^{-3}\right.$, in terms of $\mathrm{N}$ ) measured from 31 August to 25 September 2007 at $30.9 \mathrm{~m}$ (above ground) at the Weidenbrunnen site (LOD: limit of detection).

\begin{tabular}{|c|c|c|c|c|c|c|}
\hline & $\begin{array}{r}\mathrm{NH}_{3} \\
\mu \mathrm{g} \mathrm{m}^{-3}\end{array}$ & $\begin{array}{r}\mathrm{NH}_{4}^{+} \\
\mu \mathrm{g} \mathrm{m}^{-3}\end{array}$ & $\begin{array}{r}\mathrm{HNO}_{3} \\
\mu \mathrm{g} \mathrm{m}^{-3}\end{array}$ & $\begin{array}{r}\mathrm{NO}_{3}^{-} \\
\mu \mathrm{g} \mathrm{m}^{-3}\end{array}$ & $\begin{array}{r}\text { tot-NH } H_{4}^{+} \\
\mu \mathrm{g} \mathrm{m}^{-3}\end{array}$ & $\begin{array}{r}\text { tot }-\mathrm{NO}_{3}^{-} \\
\mu \mathrm{g} \mathrm{m}^{-3}\end{array}$ \\
\hline $\min$ & $<$ LOD & $<$ LOD & $<$ LOD & $<$ LOD & $<$ LOD & $<\mathrm{LOD}$ \\
\hline average & 0.67 & 0.94 & 0.19 & 0.65 & 1.73 & 0.84 \\
\hline $\max$ & 2.39 & 4.95 & 0.97 & 4.23 & 5.42 & 4.59 \\
\hline $25 \%$ quartile & 0.25 & 0.32 & 0.05 & 0.18 & 0.88 & 0.29 \\
\hline median & 0.57 & 0.76 & 0.12 & 0.48 & 1.63 & 0.70 \\
\hline $75 \%$ quartile & 1.00 & 1.39 & 0.28 & 0.80 & 2.37 & 1.08 \\
\hline
\end{tabular}

of $v_{\text {tr }}$ of around $10 \%$ (see Wolff et al., 2010). For the period 1 to 30 September 2007 the concentration data coverage was around $75 \%$. Data gaps are due to in-field blank determination, calibration, instrument failure, bad or noisy chromatograms; poor de-ionized water quality as well as air and liquid flow instability (cf. Wolff et al., 2010). Statistical distributions of $\mathrm{NH}_{3}$ and particulate $\mathrm{NH}_{4}^{+}$concentrations as well as of $\mathrm{HNO}_{3}$ and particulate $\mathrm{NO}_{3}^{-}$concentrations are presented in Table $1 . \mathrm{NH}_{3}$ concentrations ranged between 0.25 and $1.00 \mu \mathrm{g} \mathrm{m}^{-3}$ (inter-quartile range), with the median $\left(0.57 \mu \mathrm{g} \mathrm{m}^{-3}\right)$ being only slightly smaller than the one of particulate $\mathrm{NH}_{4}^{+}$of $0.76 \mu \mathrm{g} \mathrm{m}^{-3}$ (inter-quartile range between 0.32 and $\left.1.39 \mu \mathrm{g} \mathrm{m}^{-3}\right)$. $\mathrm{HNO}_{3}$ varied between 0.05 and $0.28 \mu \mathrm{g} \mathrm{m}^{-3}$ (median: $0.12 \mu \mathrm{g} \mathrm{m}^{-3}$ ), while the particulate counterpart, $\mathrm{NO}_{3}^{-}$was three to six times larger, varying between 0.18 and $0.80 \mathrm{\mu g} \mathrm{m}^{-3}$ (inter-quartile range; median: $0.48 \mu \mathrm{g} \mathrm{m}^{-3}$ ). Concentrations varied with meteorological conditions and were generally higher during periods with higher temperatures and lower RH and reached their minimum in rainy periods. During the sunny and drier days 
(Fig. 1, white bars) the overall data coverage and the percentage of significant concentration differences were higher. High RHs, rain and fog droplets may cause problems with losses in the inlet lines (Wolff et al., 2010).

\subsection{Diel variations}

The diel variations of gaseous $\mathrm{NH}_{3}$ and $\mathrm{HNO}_{3}$ and their particulate counterparts $\mathrm{NH}_{4}^{+}$and $\mathrm{NO}_{3}^{-}$are determined by production and loss (e.g., chemical production, dry deposition and phase partitioning), as well as horizontal and vertical transport within the planetary boundary layer. $\mathrm{NH}_{3}$ and particulate $\mathrm{NH}_{4}^{+}$share the same concentration range during the study and reveal a regular pattern of higher particle concentrations at night and higher gas phase concentrations during daytime, especially during the drier and sunnier episodes (cf. Fig. 2a, especially $22-25$ September). $\mathrm{HNO}_{3}$ and particulate $\mathrm{NO}_{3}^{-}$concentrations are very different, with particle concentrations of up to four times higher than gas phase concentrations (note different scales of the y-axes in Fig. 2b). Generally, $\mathrm{HNO}_{3}$ and particulate $\mathrm{NO}_{3}^{-}$concentrations also follow the pattern of high nighttime particle concentrations and high daytime gas phase concentrations. These patterns are most probably attributed to shifts in the equilibrium (Reaction R1) according to diel changes in $T$ and RH (see Figs. 1 and 2), with elevated $T$ and decreased RH during daytime with respect to night time conditions. Moreover, $\mathrm{HNO}_{3}$ is formed from the reaction of $\mathrm{NO}_{2}$ with $\mathrm{OH}$ during daytime on a time scale of three to four hours. Due to the conservative nature of tot- $\mathrm{NH}_{4}^{+}$and tot- $\mathrm{NO}_{3}^{-}$, the effect of gas-particle interactions is not of relevance in their time series (Fig. 2c). Their concentrations, however, still vary with time, reflecting meteorological conditions, with low values during rainy and foggy conditions and higher concentrations during the sunnier episodes (cf. Fig. 1). This difference between fair weather conditions and rainy/foggy episodes is more pronounced for tot- $\mathrm{NO}_{3}^{-}$, reflecting to some extent the fact that production is linked with photochemical processes (oxidation of $\mathrm{NO}_{2}$ with $\mathrm{OH}$ to $\mathrm{HNO}_{3}$ ). Tot- $\mathrm{NH}_{4}^{+}$shows a regular pattern of higher concentrations towards the afternoons, while in the time series of tot- $\mathrm{NO}_{3}^{-}$such a pattern can not be identified.

\subsection{Timescale analysis}

With changes in $T$ and RH the partitioning between gas and particle phase changed according to Reaction (R1). This is not only due to the broad diel change of $T$ and $\mathrm{RH}$, it is also due to vertical gradients of $T$ and $\mathrm{RH}$, which may be substantial above the forest canopy. Hence, thermodynamic equilibrium between the gas and particle phase according to these changes may not be established instantaneously (Meng and Seinfeld, 1996; Wexler and Seinfeld, 1992). To estimate the effect of the system striving towards equilibrium on the determination of exchange fluxes, we per- formed a timescale analysis by calculating the Damköhler number. The Damköhler number (Fig. 3), here the ratio of characteristic turbulent timescales to equilibration timescales $\left(\mathrm{Da}=\tau_{\text {turb }} / \tau_{\text {equi }}\right)$, is a measure of the degree to which chemical conversion may affect surface exchange fluxes determined by micrometeorological methods (Foken et al., 1995; Damköhler, 1940). The turbulent timescales are estimated according to Mayer (2008). The timescales to achieve thermodynamic equilibrium between gas and aerosol phase of the $\mathrm{NH}_{3}-\mathrm{HNO}_{3}-\mathrm{NH}_{4} \mathrm{NO}_{3}$ triad was calculated according to Wexler and Seinfeld $(1990,1992)$ as a function of the measured aerosol particle number concentration. Assuming that the measured aerosol number concentration only comprises inorganic aerosol particles and that all surfaces of the particles take part in the equilibrium reaction (black line in Fig. 3), Da often approaches and exceeds unity $\left(10^{\circ}\right)$, especially during nighttime. For a smaller fraction of the aerosol particle surface taking part (e.g., 10\% red line in Fig. 3), turbulent transport would be fast enough to exclude the influence of chemical divergence affecting the concentration gradients, at least during daytime $(\mathrm{Da}<0.1)$. Consequently, measured concentration differences of individual $\mathrm{N}_{\mathrm{r}}$ compounds of the $\mathrm{NH}_{3}-\mathrm{HNO}_{3}-\mathrm{NH}_{4} \mathrm{NO}_{3}$ triad were most likely affected by fast phase changes. This violates the constant flux layer assumption, a prerequisite for the application of the aerodynamic gradient method. In order to derive the "real" turbulent surface exchange flux of the individual compounds, chemical reactions have to be considered. In this paper, focusing on the ecosystem input of $\mathrm{N}_{\mathrm{r}}$ by dry deposition of total ammonium and total nitrate, we consequently confine ourselves to the derivation of fluxes of the conservative scalars, namely tot- $\mathrm{NH}_{4}^{+}$and tot- $\mathrm{NO}_{3}^{-}$, which constitute the sum of corresponding gaseous and particulate compounds.

\subsection{Fluxes and deposition velocities}

Due to the high roughness of the forest, the transfer velocity was quite large with $0.45 \pm 0.25 \mathrm{~m} \mathrm{~s}^{-1}$. Maximum transfer velocities of $0.70 \pm 0.18 \mathrm{~m} \mathrm{~s}^{-1}$ were found at noon, while during nighttime minimum values were $0.25 \pm 0.22 \mathrm{~m} \mathrm{~s}^{-1}$. From the measured concentrations at two levels above the forest canopy, we calculated the fluxes for total ammonium and total nitrate. In September, concentration measurements at two levels were available until the morning of the 26th. Fluxes varied significantly according to the prevailing meteorological conditions (see Fig. 4). Fluxes of tot- $\mathrm{NH}_{4}^{+}$ were generally smaller during fog and humid conditions and showed emission events from wet or drying surfaces and large deposition fluxes during the sunny days. Fluxes of tot- $\mathrm{NO}_{3}^{-}$were always directed downward, but were significantly larger during the sunny episodes, while being almost zero under cooler and foggy conditions. During daytime, maximum downward directed fluxes (=deposition fluxes) of tot- $\mathrm{NH}_{4}^{+}$ranged between -200 and $-500 \mathrm{ng} \mathrm{m}^{-2} \mathrm{~s}^{-1}$. Deposition fluxes of tot- $\mathrm{NO}_{3}^{-}$were about half of those of 


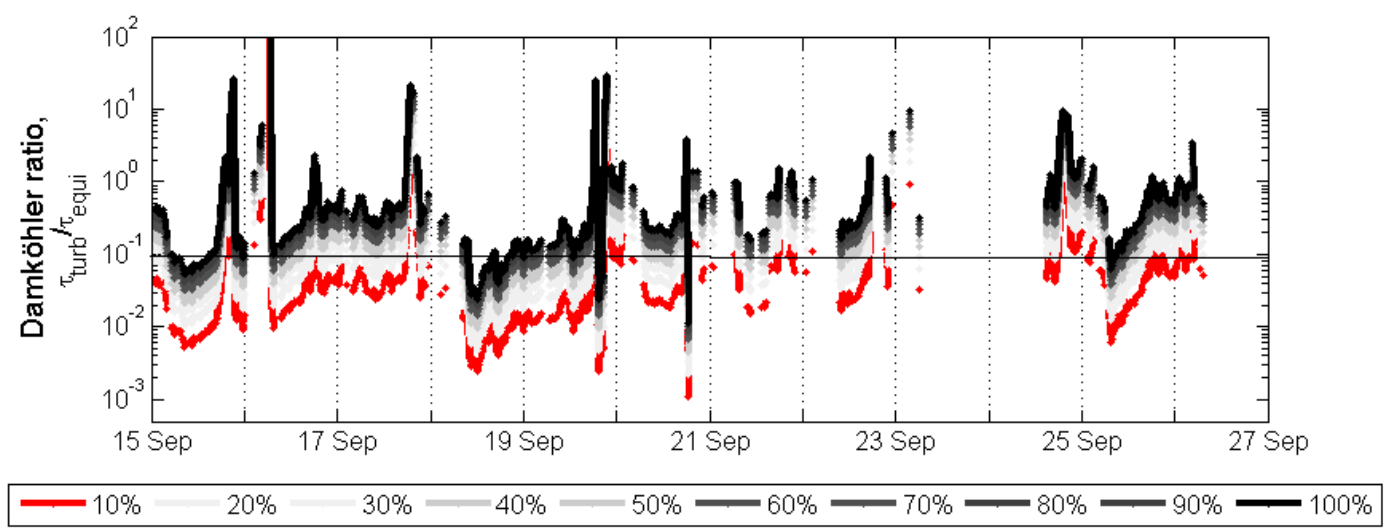

Fig. 3. Results of characteristic timescale analysis: Damköhler number $\left(\mathrm{Da}=\tau_{\text {turb }} / \tau_{\text {equi }}\right.$ ) during the EGER campaign (15-27 September 2007). Damköhler numbers for different fractions of the particle surface available for the equilibrium reaction are presented (red line: $10 \%$ and black line: $100 \%$ of the aerosol surface takes part in the equilibrium reaction).

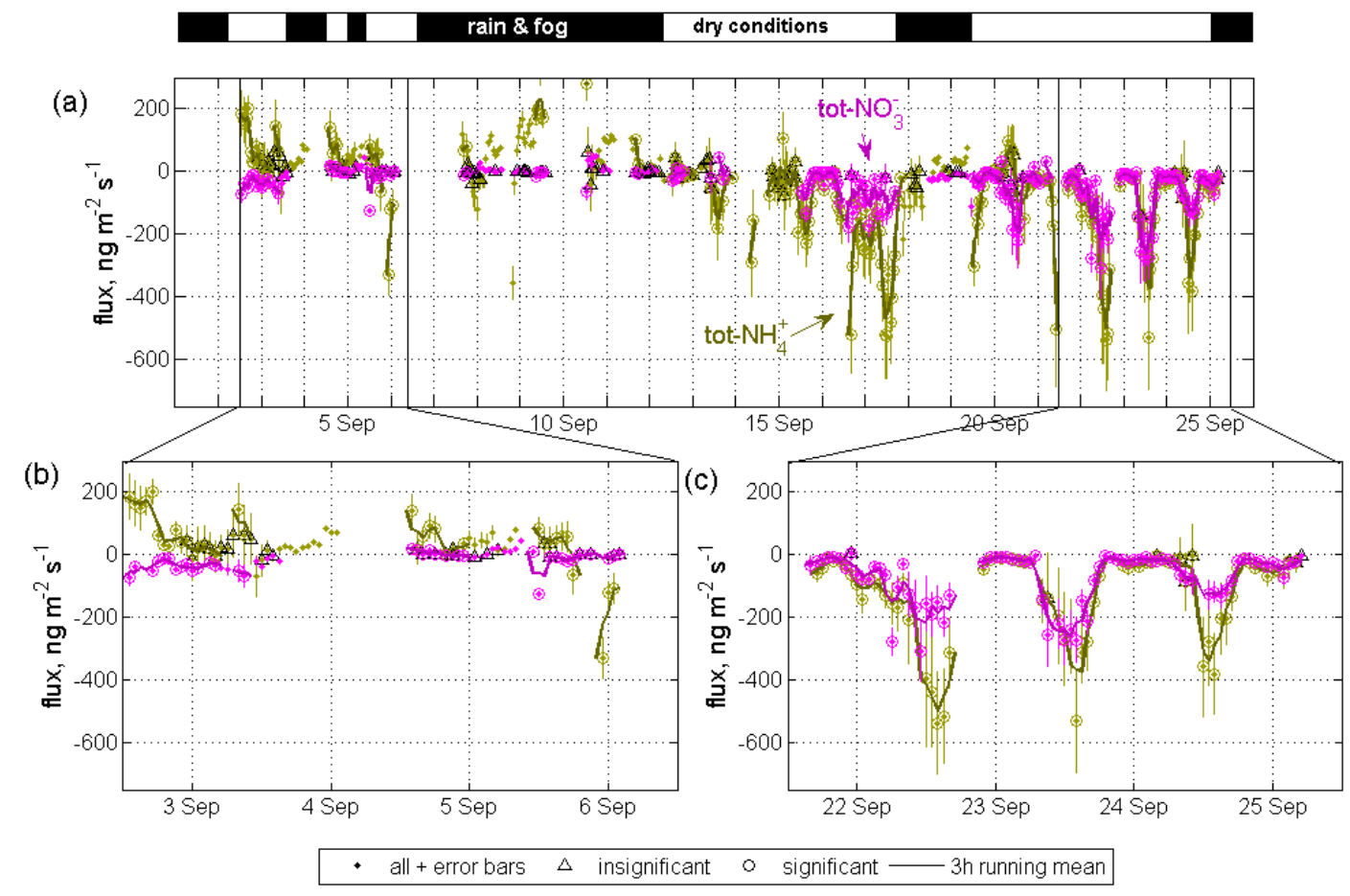

Fig. 4. Time series of tot- $\mathrm{NH}_{4}^{+}$and tot $-\mathrm{NO}_{3}^{-}$fluxes in $\mathrm{ng} \mathrm{m}^{-2} \mathrm{~s}^{-1}$ (in terms of $\mathrm{N}$ ) calculated using the AGM at the Weidenbrunnen site. An overview about the entire flux data set is given in panel (a); panels (b) and (c) show contrasting episodes: fluxes under cooler and foggy conditions (b) and fluxes during warmer and sunny conditions (c). Shown are all flux data in green and magenta dots; insignificant flux data (black triangles) are separated from significant flux data (green and magenta circles ; under conditions without rain, $\mathrm{RH}<95 \%$, and high visibility,). Additionally, a $3 \mathrm{~h}$ running mean (thick colored line) through the significant flux data is shown.

tot- $\mathrm{NH}_{4}^{+}$; the noon-time maximum ranging between -100 and $-260 \mathrm{ng} \mathrm{m}^{-2} \mathrm{~s}^{-1}$. Median flux errors for tot- $\mathrm{NH}_{4}^{+}$and tot- $\mathrm{NO}_{3}^{-}$fluxes were derived according to Wolff et al. (2010) and found to be $50 \%$ and $44 \%$, respectively. Median deposition velocities ${ }^{2}$ (or normalised fluxes; deposition veloc-

\footnotetext{
${ }^{2}$ Note here that the use of the term "deposition velocity" may be a controversial issue for species that feature bi-directional ex-
}

ity $v_{\mathrm{d}}=$ flux/concentration) were calculated at the geometric mean of the measurement heights $(13.3 \mathrm{~m}$ above displacement height) and resulted in $3.4 \mathrm{~cm} \mathrm{~s}^{-1}$ for tot- $\mathrm{NH}_{4}^{+}$

change such as $\mathrm{NH}_{3}$ and thus also tot- $\mathrm{NH}_{4}^{+}$. However, the use of a normalised flux, termed as "deposition velocity", may be useful for comparison with the aerodynamic upper limit of transport, the inverse of the aerodynamic resistance. 


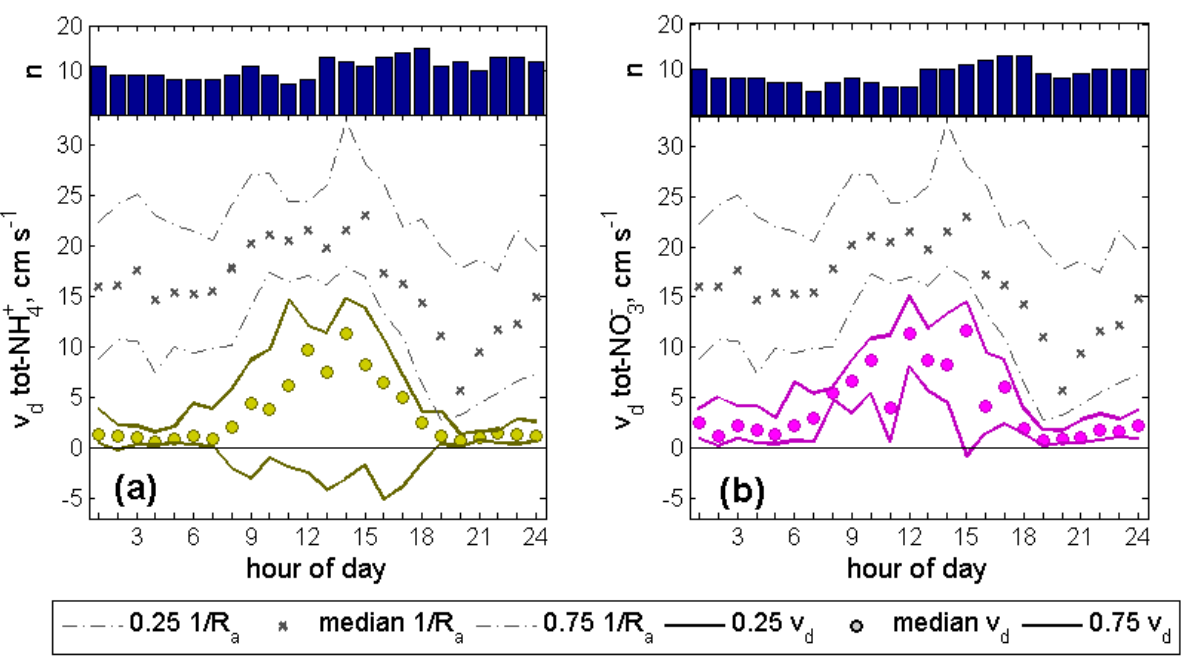

Fig. 5. Median diel variation of dry deposition velocities $\left(v_{\mathrm{d}}\right)$ for tot- $\mathrm{NH}_{4}^{+}$(left panel) and tot- $\mathrm{NO}_{3}^{-}$(right panel) with inter-quartile ranges, in $\mathrm{cm} \mathrm{s}^{-1}$, September 2007 at the Weidenbrunnen site. Only data under favourable conditions (no rain, $\mathrm{RH}<95 \%$, high visibility) are considered. Values of $1 / R_{\mathrm{a}}$ (including inter-quartile ranges) are shown as a proxy for the maximum possible $v_{\mathrm{d}}$. The number of data points used for every hour to calculate medians and inter-quartile ranges ( 0.25 and 0.75$)$ are given on top of each graph (blue bars).
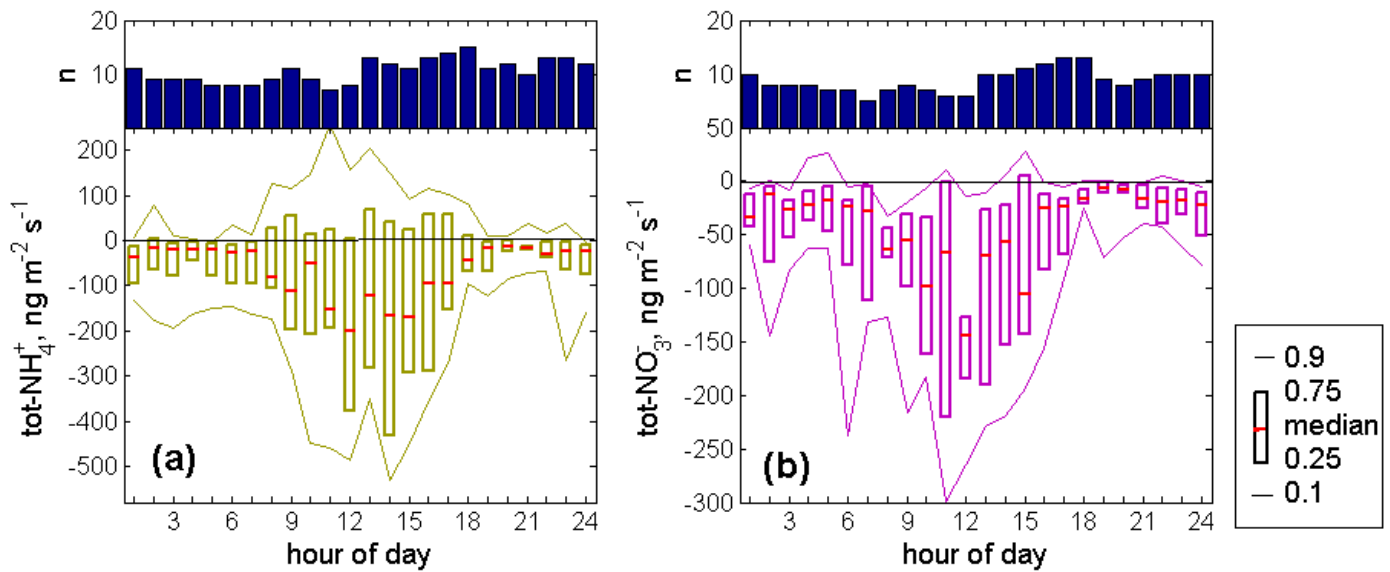

Fig. 6. Median diel variation of (a) tot- $\mathrm{NH}_{4}^{+}$flux and (b) tot- $\mathrm{NO}_{3}^{-}$flux, $\mathrm{ng} \mathrm{m}^{-2} \mathrm{~s}^{-1}$ (in terms of $\mathrm{N}$ ), from 1-30 September 2007 at the Weidenbrunnen site. Only flux data measured under favourable conditions (no rain, $\mathrm{RH}<95 \%$, high visibility) were used. Shown are the medians and inter-quartile ranges (between 25 and $75 \%$ percentiles), as well as the 10 and $90 \%$ percentiles. The number of data points used for every hour to calculate medians and percentiles are given on top of each graph (blue bars).

and $4.2 \mathrm{~cm} \mathrm{~s}^{-1}$ for tot- $\mathrm{NO}_{3}^{-}$. Especially during the sunny episodes, both $v_{\mathrm{d}}$, of tot- $\mathrm{NH}_{4}^{+}$and tot- $\mathrm{NO}_{3}^{-}$, follow closely the inverse of the aerodynamic resistance $\left(1 / R_{\mathrm{a}}\right)$, which provides a measure of the maximum possible $v_{\mathrm{d}}$. The median diel variations of $v_{\mathrm{d}}$, together with the inter-quartile ranges for tot- $\mathrm{NH}_{4}^{+}$and tot- $\mathrm{NO}_{3}^{-}$in September 2007 are shown in Fig. 5. Nighttime median $v_{\mathrm{d}}$ values are in the range of 0.6 to $1.4 \mathrm{~cm} \mathrm{~s}^{-1}$ for tot- $\mathrm{NH}_{4}^{+}$and 0.7 and $2.4 \mathrm{~cm} \mathrm{~s}^{-1}$ for tot$\mathrm{NO}_{3}^{-}$. At around $08: 00 \mathrm{~h} v_{\mathrm{d}}$ increases rapidly to maxima of around $10-12 \mathrm{~cm} \mathrm{~s}^{-1}$ for tot- $\mathrm{NH}_{4}^{+}$and to $8-12 \mathrm{~cm} \mathrm{~s}^{-1}$ for tot- $\mathrm{NO}_{3}^{-}$. The diel course of $v_{\mathrm{d}}$ is skewed somewhat towards the early afternoon; the maximum is reached at around 14:00h (tot- $\mathrm{NH}_{4}^{+}$) and 15:00 h (tot- $\mathrm{NO}_{3}^{-}$). Afterwards, $v_{\mathrm{d}}$ drops again, reaching the lower nighttime values at around 18:00 h/19:00 h. Median $v_{\mathrm{d}}$ values for both, tot- $\mathrm{NH}_{4}^{+}$and tot$\mathrm{NO}_{3}^{-}$, remain below the aerodynamically maximum possible value, indicated as $1 / R_{\mathrm{a}}$.

\subsection{Total $\mathbf{N}$ deposition in September 2007}

Major constituents of dry $\mathrm{N}_{\mathrm{r}}$ deposition are particulate $\mathrm{NH}_{4}^{+}$and $\mathrm{NO}_{3}^{-}$and gaseous compounds $\mathrm{NH}_{3}, \mathrm{HNO}_{3}$ and to a minor extent also nitrogen dioxide $\left(\mathrm{NO}_{2}\right)$, nitrous acid (HONO), peroxyacetyl nitrate (PAN), and nitric oxide (NO) (Andersen and Hovmand, 1999). Surface-atmosphere 


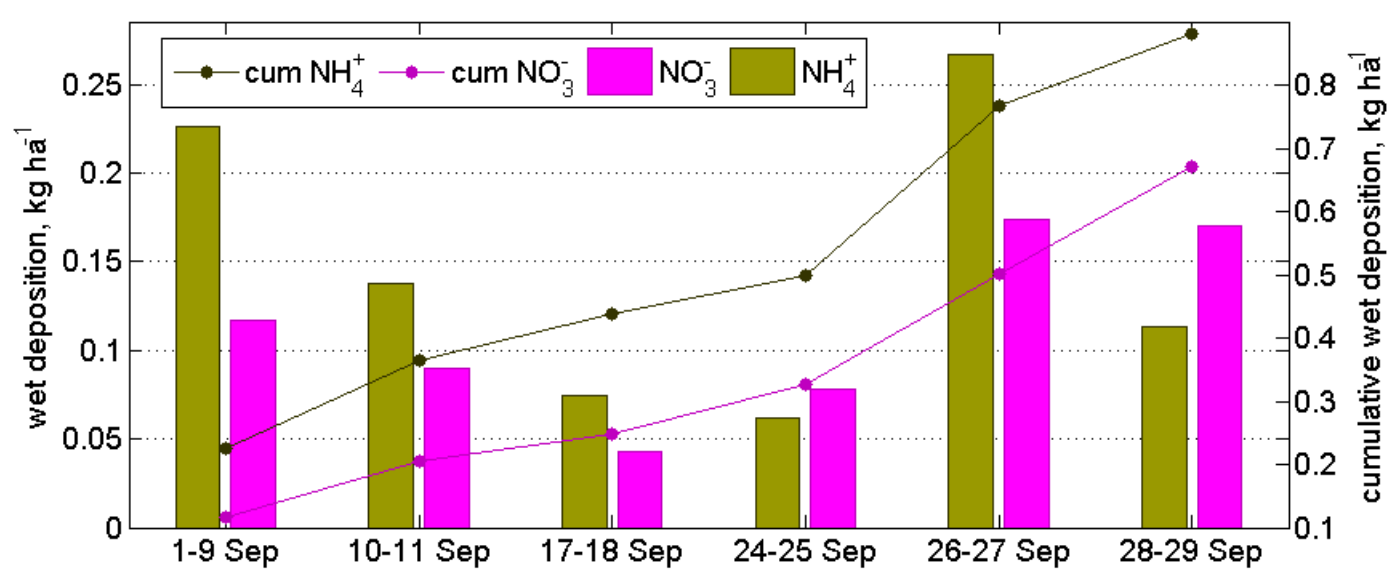

Fig. 7. Wet deposition of $\mathrm{NH}_{4}^{+}$and $\mathrm{NO}_{3}^{-}$in September 2007 at the Weidenbrunnen site. Indicated are wet deposition amounts per event (in $\mathrm{kg} \mathrm{ha}^{-1}$ in terms of $\mathrm{N}$, left scale) and cumulative (cum) values for the entire month September 2007 (right scale).

exchange fluxes of $\mathrm{NO}$ and $\mathrm{NO}_{2}$ measured by eddy covariance at our site were found to be one order of magnitude lower than the fluxes of tot- $\mathrm{NH}_{4}^{+}$and tot- $\mathrm{NO}_{3}^{-}$(Tsokankunku et al., 2009). The daytime NO flux was directed downward to the forest canopy with -5 to $-7 \mathrm{ng} \mathrm{m}^{-2} \mathrm{~s}^{-2}$ (in terms of $\mathrm{N}$, inter-quartile range) and the daytime $\mathrm{NO}_{2}$ flux was directed upward with about 14 to $28 \mathrm{ng} \mathrm{m}^{-2} \mathrm{~s}^{-2}$ (interquartile range). The directions of $\mathrm{NO}$ and $\mathrm{NO}_{2}$ fluxes are in contrast to what would be expected for low vegetation (Delany and Lenschow, 1987), however they are mainly due to chemically induced flux divergence (Meixner, 1993). Concentrations of HONO were in the order of 0.03 to $0.09 \mu \mathrm{g} \mathrm{m}^{-3}$ (inter-quartile range), and concentrations of PAN were not measured at the site. Hence, the high importance of tot- $\mathrm{NH}_{4}^{+}$and tot- $\mathrm{NO}_{3}^{-}$in $\mathrm{N}_{r}$ deposition generally recognized (Erisman and Draaijers, 2003; Erisman et al., 2003, 2005a, 2007; Andersen and Hovmand, 1999; Asman et al., 1998; Galloway et al., 2008; Sutton et al., 2007) is confirmed by our study. Median diel tot- $\mathrm{NH}_{4}^{+}$and tot$\mathrm{NO}_{3}^{-}$dry deposition fluxes for September 2007 are presented in Fig. 6. Fluxes were larger during daytime, median tot$\mathrm{NH}_{4}^{+}$fluxes reached $-197 \mathrm{ng} \mathrm{m}^{-2} \mathrm{~s}^{-1}$, while median tot$\mathrm{NO}_{3}^{-}$fluxes reached $-134 \mathrm{ng} \mathrm{m}^{-2} \mathrm{~s}^{-1}$. Median nighttime values were around zero to $-40 \mathrm{ng} \mathrm{m}^{-2} \mathrm{~s}^{-1}$ for tot- $\mathrm{NH}_{4}^{+}$and -7 to $-20 \mathrm{ng} \mathrm{m}^{-2} \mathrm{~s}^{-1}$ for tot- $\mathrm{NO}_{3}^{-}$. The dry deposition for the whole month of September was estimated from the median diel deposition (tot- $\mathrm{NH}_{4}^{+}: 5.68 \mathrm{mg} \mathrm{m}^{-2} \mathrm{~d}^{-1}$ and tot$\mathrm{NO}_{3}^{-}: 3.54 \mathrm{mg} \mathrm{m}^{-2} \mathrm{~d}^{-1}$ ) multiplied by the number of days in September (30). This method was used because we do not have uninterrupted flux measurements, especially under foggy and rainy conditions, when the instrument worked less reliable (see above and Wolff et al., 2010). Flux values derived from non-significant concentration differences were also included in the calculation, as these were usually close to zero and had thus a significant influence on the median. We estimated the dry deposition of tot- $\mathrm{NH}_{4}^{+}$and tot- $\mathrm{NO}_{3}^{-}$ to $1.7 \mathrm{~kg} \mathrm{ha}^{-1}$ and $1.1 \mathrm{~kg} \mathrm{ha}^{-1}$, respectively. If we excluded the insignificant flux values, the deposition for the month of September would be overestimated by $38 \%$ in the case of tot- $\mathrm{NH}_{4}^{+}$and by $28 \%$ in the case of tot- $\mathrm{NO}_{3}^{-}$.

Wet deposition was calculated from rain samples (analyzed by ion-chromatography) taken at the nearby clearing from six rain events in September 2007 (cf. Fig. 1). In most of the rain samples $\mathrm{NH}_{4}^{+}$was dominating over $\mathrm{NO}_{3}^{-}$(Fig. 7) with concentrations being about one third larger. In the rain storm after the six days of sunshine (19-25 September), $\mathrm{NO}_{3}^{-}$ concentrations were higher, which was also the case at the end of September. For September 2007, wet $\mathrm{NH}_{4}^{+}$deposition was calculated to $0.9 \mathrm{~kg} \mathrm{ha}^{-1}$ and $\mathrm{NO}_{3}^{-}$to $0.7 \mathrm{~kg} \mathrm{ha}^{-1}$, their sum yielding $1.6 \mathrm{~kg} \mathrm{ha}^{-1}$.

In both, wet and dry deposition, $\mathrm{NH}_{4}^{+}$dominated over $\mathrm{NO}_{3}^{-}, \mathrm{NO}_{3}^{-}$deposition being roughly two thirds of the $\mathrm{NH}_{4}^{+}$ deposition. The dry deposition was almost twice the amount of the wet deposition. The total $\mathrm{N}$ deposition due to dry and wet deposition of tot- $\mathrm{NH}_{4}^{+}$and tot- $\mathrm{NO}_{3}^{-}$yielded $4.3 \mathrm{~kg} \mathrm{ha}^{-1}$ (with $64 \%$ due to dry deposition and $36 \%$ due to wet deposition) in September 2007.

\section{Discussion}

\subsection{Fluxes and deposition velocities}

Concentrations levels of gaseous $\mathrm{NH}_{3}$ and $\mathrm{HNO}_{3}$ and particulate $\mathrm{NH}_{4}^{+}$and $\mathrm{NO}_{3}^{-}$, observed in our study (Fig. 2) are comparable to previous observations at the Weidenbrunnen site (Held et al., 2002). The dominance of tot- $\mathrm{NH}_{4}^{+}$over tot- $\mathrm{NO}_{3}^{-}$indicates the prevailing influence of emissions from agricultural activities as compared to traffic emissions. The dominance of the particulate phase over the respective gas phase was also observed by Held et al. (2002). 
Flux values and values of $v_{\mathrm{d}}$ derived in this study are relatively large. There are indications that the exchange of reactive species at our site is not limited by any surface resistance. In summer 2001 exchange fluxes of hydrogen peroxide $\left(\mathrm{H}_{2} \mathrm{O}_{2}\right)$ were determined at our site using a relaxed eddy accumulation technique (Valverde-Canossa et al., 2006). The characteristics of $\mathrm{H}_{2} \mathrm{O}_{2}$ are comparable to $\mathrm{HNO}_{3}$, as it is produced above the canopy in the gas phase (mainly by recombination of two $\mathrm{HO}_{2}$ radicals) with sinks in the particulate phase and efficient dry deposition to surfaces due to its high solubility and reactivity (Hall et al., 1999; Walcek, 1987). A modelling analysis indicated that $\mathrm{H}_{2} \mathrm{O}_{2}$ exchange was largely controlled by turbulent transport to and into the canopy, and also by the supply from above where chemical production occurs (Ganzeveld et al., 2006). Measured daytime $v_{\mathrm{d}}$ of $\mathrm{H}_{2} \mathrm{O}_{2}$ were $5 \pm 2 \mathrm{~cm} \mathrm{~s}^{-1}$ (Valverde-Canossa et al., 2006).

Most previous studies derived fluxes of individual $\mathrm{N}_{\mathrm{r}}$ compounds only or derived total fluxes using the inferential method that is constrained by required parameterizations of surface related exchange parameters (see Sect. 1). We found only one study (Sievering et al., 1994) that reported directly measured tot- $\mathrm{NO}_{3}^{-}$fluxes (using AGM) and $v_{\mathrm{d}}$ above a forest. They found evidence for large deposition rates of tot$\mathrm{NO}_{3}^{-}$above a predominately spruce forest (Bayrischer Wald) in Germany (approx. $250 \mathrm{~km} \mathrm{SE}$ from our site). They measured concentrations of particulate $\mathrm{NH}_{4}^{+}, \mathrm{NO}_{3}^{-}$and gaseous $\mathrm{NH}_{3}$ and $\mathrm{HNO}_{3}$ at two levels, using filter packs. Tot-NOconcentrations were about half of our observed values, ranging between 0.34 and $0.68 \mathrm{~g} \mathrm{~m} \mathrm{~m}^{-3}$. Particulate $\mathrm{NO}_{3}^{-}$contributed $15-20 \%$ to the tot- $\mathrm{NO}_{3}^{-}$. The found diel tot- $\mathrm{NO}_{3}^{-}$ flux ranged from -5.2 to $-0.7 \mathrm{mg} \mathrm{m}^{-2} \mathrm{~s}^{-1}$, which is very similar to what we found. The observed geometric median mass diameters of $\mathrm{NO}_{3}^{-}$and $\mathrm{NH}_{4}^{+}$containing aerosol particles were $2.24 \pm 0.85 \mu \mathrm{m}$ and $<0.9 \mu \mathrm{m}$, respectively. For these particle diameters, Peters and Eiden (1992) modelled potential $v_{\mathrm{d}}$ of $2-8 \mathrm{~cm} \mathrm{~s}^{-1}$ for the particulate $\mathrm{NO}_{3}^{-}$dry deposition at the Bayrische Wald site. Values of tot- $\mathrm{NO}_{3}^{-}$ dry deposition velocities derived by Sievering et al. (1994) were in the range of $2-9 \mathrm{~cm} \mathrm{~s}^{-1}$, being approximately equal for $\mathrm{HNO}_{3}$ and $\mathrm{NO}_{3}^{-}$. Due to large uncertainties in particulate $\mathrm{NH}_{4}^{+}$measurement, they could not determine exchange fluxes and/or $v_{\mathrm{d}}$ 's of tot- $\mathrm{NH}_{4}^{+}$. Since the particulate phase dominated our measured concentrations (see Sect. 3.2) we presume that they also dominate the deposition fluxes, at least in tot- $\mathrm{NO}_{3}^{-}$. Aerosol particle fluxes and $v_{\mathrm{d}}$ 's depend on particle diameter, atmospheric conditions (friction velocity and stability) and surface conditions, such as roughness and canopy morphology (Erisman et al., 1997; Gallagher et al., 1997; Peters and Eiden, 1992; Fowler et al., 2009). Reported $v_{\mathrm{d}}$ 's range from some $\mathrm{mms}^{-1}$ (small particles $(<1 \mu \mathrm{m})$; low wind speed) to more than $10 \mathrm{~cm} \mathrm{~s}^{-1}$ (larger particles $(>10 \mu \mathrm{m})$; high wind speed). The high roughness and the large surface of the needles of the spruce forest at our site combined with the aerodynamic regime of high friction ve- locities (inter-quartile range $0.32-0.63 \mathrm{~m} \mathrm{~s}^{-1}$ ) partly explain our findings for $v_{\mathrm{d}}$ 's of large aerosol particles (Fowler et al., 2009). Furthermore, the $50 \%$ theoretical particle cut-off diameters of the GRAEGOR due to inlet design and denuder airflow regime is $0.2 \mathrm{~nm}$ and $18 \mu \mathrm{m}$ (Thomas et al., 2009). According to Peters and Eiden (1992) $v_{\mathrm{d}}$ of aerosol particles captured by the GRAEGOR at typical wind speeds at our site (2-4 $\left.\mathrm{m} \mathrm{s}^{-1}\right)$ may have varied between 0.08 and more than $10 \mathrm{~cm} \mathrm{~s}^{-1}$. Measurements at the Weidenbrunnen site by Held et al. (2002) revealed consistent patterns in the size distributions of particulate $\mathrm{NH}_{4}^{+}$and $\mathrm{NO}_{3}^{-}$, with the former one dominating the fine particle concentrations (mean particle diameter of 0.25 and $0.71 \mu \mathrm{m}$ ), and the latter dominating the coarse particles ranges (mean particle diameter of 0.71 and $2 \mu \mathrm{m})$. For particles with mean diameters of $0.25,0.71$ and $2 \mu \mathrm{m}, v_{\mathrm{d}}$ at the encountered wind speeds would theoretically range between $0.01-0.6,0.01-1.08$, and $0.06-3.5 \mathrm{~cm} \mathrm{~s}^{-1}$, respectively (Peters and Eiden, 1992). According to Gallagher et al. (1997) these values would be 0.05-1, 0.03-2, and 0.11$0.8 \mathrm{~cm} \mathrm{~s}^{-1}$. Thus, another possible explanation for the large $v_{\mathrm{d}}$ found in our study (Sect. 3.5 and Fig. 5), could be the presence of large $(\geq 10 \mu \mathrm{m}) \mathrm{NH}_{4}^{+}$and $\mathrm{NO}_{3}^{-}$containing particles.

Deposition velocities of $\mathrm{NH}_{4}^{+}$and $\mathrm{NO}_{3}^{-}$(derived by eddy covariance measurements) larger than those of $\mathrm{SO}_{4}^{2-}$ and those derived from particle number flux measurements have been reported (Nemitz et al., 2004b; Thomas, 2007). These were explained by changes in the thermodynamic equilibrium towards the more rapidly depositing gaseous species between the measurement height and the vegetated surface (Fowler et al., 2009). The quick removal processes of $\mathrm{NH}_{3}$ and $\mathrm{HNO}_{3}$ just above and within the canopy together with warm surface temperatures would favour aerosol evaporation, consequently enhancing total deposition of both, particulate and gaseous phase. We observed highest $v_{\mathrm{d}}$ 's during daytime of the sunny episodes during our measurement period. During these times, temperature was highest at the canopy top. Although using the chemically conservative quantities of tot- $\mathrm{NH}_{4}^{+}$and tot- $\mathrm{NO}_{3}^{-}$, the derived total deposition fluxes were probably influenced by this additional sink, resembling thus more the $v_{\mathrm{d}}$ 's of gaseous species than those of particles. Assuming such a mechanism we can follow up reports which claimed the importance of particulate $\mathrm{N}$ species in $\mathrm{N}$ deposition estimates and the use of effective deposition velocity parameterisations for highly volatile aerosol compounds rather than using parameterisations regardless of the particulates' chemical composition (Erisman et al., 1995, 1997; Fowler et al., 2009).

\subsection{Deposition of reactive nitrogen}

Due to the high frequency of fog events at our mountainous research site throughout the year and throughout our measurement period (see meteorological conditions, Fig. 1), the deposition through fog water interception needs to be included in a monthly input estimate of $\mathrm{N}_{\mathrm{r}}$ (Klemm and 
Wrzesinsky, 2007; Zimmermann and Zimmermann, 2002). Several studies on fog meteorology and chemistry have been conducted at the site (Klemm and Wrzesinsky, 2007; Wrzesinsky and Klemm, 2000), in which the importance of the so called occult deposition was stressed. For a study between April 2001 and March 2002, most fog events were found to be associated with clouds being advected from westerly directions, intercepting with the forest vegetation of the site as it is located on a mountain range of about $1000 \mathrm{~m}$ a.s.l. (Klemm and Wrzesinsky, 2007). The most important ionic constituents of fog water were found to be $\mathrm{NH}_{4}^{+}, \mathrm{NO}_{3}^{-}$and $\mathrm{SO}_{4}^{2-}$. These three ions were significantly enriched in the fog water compared to the rain water samples (ratios fog/rain concentrations 18.1, 12.7 and 11.8, respectively), which led to the conclusion that during the study of April 2001 and March 2002 the occult deposition of $\mathrm{NH}_{4}^{+}, \mathrm{NO}_{3}^{-}$and $\mathrm{SO}_{4}^{2-}$ in fog water was similar and often larger than the wet deposition, although more liquid water was deposited through rain than through fog. Accounting these findings, we estimate the occult deposition in September 2007 as equal to the wet deposition. Consequently, the total $\mathrm{N}_{\mathrm{r}}$ deposition in September 2007 sums up to $5.9 \mathrm{~kg} \mathrm{ha}^{-1}$.

The wet deposition rates of $\mathrm{NH}_{4}^{+}$and $\mathrm{NO}_{3}^{-}$measured in summer 2001 at the Weidenbrunnen site were very similar to ours, with September sums being $0.85 \mathrm{~kg} \mathrm{ha}^{-1} \mathrm{NH}_{4}^{+}$and $0.84 \mathrm{~kg} \mathrm{ha}^{-1} \mathrm{NO}_{3}^{-}$(see Klemm and Wrzesinsky, 2007).

Zimmermann et al. (2006) estimated dry deposition inputs of tot- $\mathrm{NH}_{4}^{+}$and tot- $\mathrm{NO}_{3}^{-}$by inferential modelling for a spruce forest in south-east Germany (about $150 \mathrm{~km}$ northeast from our site, $735 \mathrm{~m}$ a.s.1.). Although mean concentrations were very similar to the concentrations we measured, their deposition was about half of our values with values of September (mean of the years 2002-2004) of $1.2 \mathrm{~kg} \mathrm{ha}^{-1}$ dry deposition and $0.9 \mathrm{~kg} \mathrm{ha}^{-1}$ wet deposition of tot- $\mathrm{NH}_{4}^{+}$and tot- $\mathrm{NO}_{3}^{-}$. One reason for the deviation of dry deposition values could be the use of an inferential model by Zimmermann et al. (2006). Measured throughfall fluxes during the same period where about two thirds of the total deposition fluxes (the sum of modelled dry deposition, wet deposition and fog interception) indicating the effect of canopy uptake of $\mathrm{NH}_{4}^{+}$ and $\mathrm{NO}_{3}^{-}$on the throughfall results. For the "Fichtelgebirge" mountains, Matzner et al. (2001) reported average throughfall fluxes of mineral $\mathrm{N}$ of $21 \mathrm{~kg} \mathrm{ha}^{-1} \mathrm{yr}^{-1}$, pointing out that this value underestimates the actual atmospheric deposition due to the canopy uptake, which they estimate as high as $28 \mathrm{~kg} \mathrm{ha}^{-1} \mathrm{yr}^{-1}$. Assuming equally distributed deposition throughout the year, these values correspond to a monthly deposition of around 1.8 to $2.3 \mathrm{~kg} \mathrm{ha}^{-1}$ month $^{-1}$. The comparison between our short-term measurements based on the AGM method with annual throughfall data is not straight forward. Apart from the differences in the measurement approach, different time periods of investigation are compared and the assumed equally distributed deposition throughout the year may not be given.
We found two studies with direct deposition estimates (AGM), reporting annual deposition values of tot- $\mathrm{NH}_{4}^{+}$ and tot $-\mathrm{NO}_{3}^{-}$. Direct deposition estimates of different $\mathrm{N}_{r}$ species for the year 1995 at the Speuld forest in The Netherlands were reported by Erisman et al. (1996). Dry deposition rates of tot- $\mathrm{NH}_{4}^{+}$and tot- $\mathrm{NO}_{3}^{-}$ were $22.6 \mathrm{~kg} \mathrm{ha}^{-1} \mathrm{yr}^{-1}$ and $4.7 \mathrm{~kg} \mathrm{ha}^{-1} \mathrm{yr}^{-1}$ (corresponding to monthly deposition rates of roughly $1.9 \mathrm{~kg} \mathrm{ha}^{-1}$ month $^{-1}$ and $0.4 \mathrm{~kg} \mathrm{ha}^{-1}$ month $^{-1}$ ), respectively. Reported wet deposition rates were $11.3 \mathrm{~kg} \mathrm{ha}^{-1} \mathrm{yr}^{-1}\left(\sim 0.9 \mathrm{~kg} \mathrm{ha}^{-1} \mathrm{month}^{-1}\right)$ for $\mathrm{NH}_{4}^{+}$and $5.2 \mathrm{~kg} \mathrm{ha}^{-1} \mathrm{yr}^{-1}\left(\sim 0.4 \mathrm{~kg} \mathrm{ha}^{-1} \mathrm{month}^{-1}\right)$ for $\mathrm{NO}_{3}^{-}$. Total $\mathrm{N}$ deposition (the sum of dry and wet deposition) yielded $43.8 \mathrm{~kg} \mathrm{ha}^{-1} \mathrm{yr}^{-1}\left(3.7 \mathrm{~kg} \mathrm{ha}^{-1}\right.$ month $\left.^{-1}\right)$, which is very similar to our estimates (when looking at dry and wet deposition). Andersen and Hovmand (1999) report dry deposition estimates derived using the AGM $\left(\mathrm{NH}_{3}\right)$ and inferential modelling $\left(\mathrm{HNO}_{3}, \mathrm{NO}_{3}^{-}, \mathrm{NH}_{4}^{+}\right)$for one year (July 1995 to June 1996) of $9.2 \mathrm{~kg} \mathrm{ha}^{-1} \mathrm{yr}^{-1}$ of tot- $\mathrm{NH}_{4}^{+}$ and $2.2 \mathrm{~kg} \mathrm{ha}^{-1} \mathrm{yr}^{-1}$ of tot- $\mathrm{NO}_{3}^{-}$for a Norway spruce forest site in west Denmark. Expressed as monthly deposition rates, these values correspond to about $0.8 \mathrm{~kg} \mathrm{ha}^{-1}$ month $^{-1}$ of tot- $\mathrm{NH}_{4}^{+}$and $0.2 \mathrm{~kg} \mathrm{ha}^{-1}$ month ${ }^{-1}$ tot- $\mathrm{NO}_{3}^{-}$In Denmark the dry deposition of $\mathrm{N}_{\mathrm{r}}$ compounds to forest ecosystems contributes with $50 \%-67 \%$ to the total $\mathrm{N}_{r}$ deposition (Andersen and Hovmand, 1999). Thus, the total $\mathrm{N}_{r}$ deposition would yield an annual deposition flux of 17.1 to $22.8 \mathrm{~kg} \mathrm{ha}^{-1} \mathrm{yr}^{-1}$ (corresponding to monthly deposition of about 1.4 to $1.9 \mathrm{~kg} \mathrm{ha}^{-1}$ month $^{-1}$ ).

Although the comparison between our measurement results with values estimated from annual values is very rough, the match to long term direct measurements in The Netherlands (Erisman et al., 1996) is remarkably good. Additionally, the ratio of dry to wet deposition compares very well with this study. Occult deposition was only measured in two studies and the importance of this deposition pathway at our site was stressed (Zimmermann et al., 2006; Klemm and Wrzesinsky, 2007). All of the studies, with which we compared our results, were conducted above/in spruce forest. Rothe et al. (2002) and Berger et al. (2008, 2009) compared deposition loads between beech, mixed and spruce forests and found enhanced acid deposition in the spruce forests due to the more efficiently scavenging of the coniferous canopies, which is also reflected in higher seepage rates of $\mathrm{NO}_{3}$. The high surface to volume ratio of the canopy may thus also enhance dry deposition.

\section{Conclusion}

An intensive field campaign with hourly resolved twolevel measurements of ammonia $\left(\mathrm{NH}_{3}\right)$, nitric acid $\left(\mathrm{HNO}_{3}\right)$, particulate ammonium $\left(\mathrm{NH}_{4}^{+}\right)$and nitrate $\left(\mathrm{NO}_{3}^{-}\right)$were conducted above a spruce forest in southeast Germany. For the first time, the complete $\mathrm{NH}_{3}-\mathrm{HNO}_{3}-\mathrm{NH}_{4} \mathrm{NO}_{3}$ triad 
was measured continuously and simultaneously at two levels above a forest canopy, aiming estimates of surfaceatmosphere fluxes using the aerodynamic gradient method. However, indications for rapid phase changes in the $\mathrm{NH}_{3}$ $\mathrm{HNO}_{3}-\mathrm{NH}_{4} \mathrm{NO}_{3}$ triad required confinement to exchange fluxes of the chemically conservative quantities tot- $\mathrm{NH}_{4}^{+}$and tot- $\mathrm{NO}_{3}^{-}$(i.e. sums of corresponding gaseous and particulate compounds). In September 2007 exchange fluxes were comparatively large and median daily dry deposition velocities were $3.4 \mathrm{~cm} \mathrm{~s}^{-1}$ for tot- $\mathrm{NH}_{4}^{+}$and $4.2 \mathrm{~cm} \mathrm{~s}^{-1}$ for tot- $\mathrm{NO}_{3}^{-}$. Large deposition velocities of tot- $\mathrm{NH}_{4}^{+}$and tot- $\mathrm{NO}_{3}^{-}$were most likely the result of a combination of several effects, such as:

1. high roughness of the forest canopy, large receptor surfaces (needles) of coniferous trees, and surface resistances of tot- $\mathrm{NH}_{4}^{+}$and tot- $\mathrm{NO}_{3}^{-}$close to zero,

2. partly presence of particulate $\mathrm{NO}_{3}^{-}$in large aerosol particles (i.e. $\geq 10 \mu \mathrm{m}$, typically featuring large deposition velocities due to the influence of gravitational settling),

3. potential strong chemical sink below our measurement height due to phase changes between $\mathrm{NH}_{3}, \mathrm{HNO}_{3}$ and $\mathrm{NH}_{4} \mathrm{NO}_{3}$ towards the more efficiently deposited gases

Consequently, we like to state, that performing concentration measurements of only one single compound of the $\mathrm{NH}_{3}$ $\mathrm{HNO}_{3}-\mathrm{NH}_{4} \mathrm{NO}_{3}$ triad at one single level above forest and deriving fluxes from this concentration data by inferential modelling (applying empirically obtained $R_{\mathrm{c}}$ values) may lead to underestimation of the actual deposition load, especially in the case of $\mathrm{NH}_{4}^{+}$and $\mathrm{NO}_{3}^{-}$containing aerosol particles. In our study, tot- $\mathrm{NH}_{4}^{+}$dry and wet deposition was larger than the respective tot- $\mathrm{NO}_{3}^{-}$deposition. The derived monthly deposition of tot- $\mathrm{NH}_{4}^{+}$and tot- $\mathrm{NO}_{3}^{-}$, as sum from dry, wet, and occult (fog interception) deposition is at the upper end of the range reported in the literature so far. Thus, our site is definitely a significant receptor region for reactive nitrogen.

Acknowledgements. The authors gratefully acknowledge financial support from the German Science Foundation (DFG project EGER, ME 2100/4-1) and from the Max Planck Society. The authors wish to thank the University of Bayreuth (Micrometeorology Department) for hosting and supporting us during the EGER study. We thank the Bavarian Environment Agency (LfU) for the analysis of the rain water samples. For very valuable support in the field measurements we would like to express our gratitude to the whole EGER IOP1 crew, especially to D. Plake and J. Sintermann.

The service charges for this open access publication have been covered by the Max Planck Society.

Edited by: C. Spirig

\section{References}

Alsheimer, M.: Charakterisierung räumlicher und zeitlicher Heterogenitäten der Transpiration unterschiedlicher montaner Fichtenbestände durch Xylemflussmessungen, Bayreuther Forum Ökologie, 1-143, 1997.

Ammann, C.: On the applicability of relaxed eddy accumulation and common methods for measuring trace gas fluxes, $\mathrm{PhD}, \mathrm{Ge}-$ ographisches Institut, ETH, Zürich, 229 pp., 1998.

Andersen, H. V. and Hovmand, M. F.: Review of dry deposition measurements of ammonia and nitric acid to forest, For. Ecol. Manage., 114, 5-18, 1999.

Asman, W. A. H., Sutton, M. A., and Schjorring, J. K.: Ammonia: emission, atmospheric transport and deposition, New Phytologist, 139, 27-48, 1998.

Berger, T. W., Untersteiner, H., Schume, H., and Jost, G.: Throughfall fluxes in a secondary spruce (Picea abies), a beech (Fagus sylvatica) and a mixed spruce-beech stand, For. Ecol. Manage., 255, 605-618, 2008.

Berger, T. W., Untersteiner, H., Toplitzer, M., and Neubauer, C.: Nutrient fluxes in pure and mixed stands of spruce (Picea abies) and beech (Fagus sylvatica), Plant and Soil, 322, 317-342, 2009.

Brost, R. A., Delany, A. C., and Huebert, B. J.: Numerical Modeling of Concentrations and Fluxes of $\mathrm{HNO}_{3}, \mathrm{NH}_{3}$, and $\mathrm{NH}_{4} \mathrm{NO}_{3}$ near the Surface, J. Geophys. Res.-Atmos., 93, 7137-7152, 1988.

Damköhler, G.: Der Einfluss der Turbulenz auf die Flammengeschwindigkeit in Gasgemischen, Zeitschrift für Eletktrochemie, 46, 601-652, 1940.

De Arellano, J. V. and Duynkerke, P. G.: Influence of chemistry on the flux-gradient relationships for the $\mathrm{NO}-\mathrm{O}_{3}-\mathrm{NO}_{2}$ system, Bound.-Lay. Meteorol., 61, 375-387, 1992.

Delany, A. C. and Lenschow, D. H.: Measurement of $\mathrm{NO}$ and $\mathrm{NO}_{2}$ Soil Crop Level Fluxes with a Micrometeorological Technique, Abstr. Pap. Am. Chem. Soc., 193, 174-ENVR, 1987.

Eigenbrodt: Betriebs- und Wartungsanleitung Automatischer Niederschlagssammler NSA 181/KHS, Eigenbrodt GmbH \& Co. KG., 2007.

Erisman, J. W., Draaijers, G., Duyzer, J., Hofschreuder, P., Vanleeuwen, N., Romer, F., Ruijgrok, W., and Wyers, P.: Particle deposition to forests, Acid Rain Research: Do We Have Enough Answers?, 64, 115-126, 1995.

Erisman, J. W., Draaijers, G. P. J., Mennen, M. G., Hogenkamp, J. E. M., van Putten, E., Uiterwijk, W., Kemkers, E., Wiese, H., Duyzer, J. H., Otjes, R., and Wyers, G. P.: Towards development of a deposition monitoring network for air pollution of Europe, RIVM, Bilthoven, The Netherlands, 722108014, 1996.

Erisman, J. W., Draaijers, G., Duyzer, J., Hofschreuder, P., VanLeeuwen, N., Romer, F., Ruijgrok, W., Wyers, P., and Gallagher, M.: Particle deposition to forests - Summary of results and application, Atmos. Environ., 31, 321-332, 1997.

Erisman, J. W. and Draaijers, G.: Deposition to forests in Europe: most important factors influencing dry deposition and models used for generalisation, Environ. Pollut., 124, 379-388, 2003.

Erisman, J. W., Grennfelt, P., and Sutton, M.: The European perspective on nitrogen emission and deposition, Environ. Int., 29 311-325, 2003.

Erisman, J. W., Hensen, A., Mosquera, J., Sutton, M., and Fowler, D.: Deposition monitoring networks: what monitoring is required to give reasonable estimates of ammonia/ammonium?, Environ. Pollut., 135, 419-431, 2005a. 
Erisman, J. W., Vermeulen, A., Hensen, A., Flechard, C., Dammgen, U., Fowler, D., Sutton, M., Grunhage, L., and Tuovinen, J. P.: Monitoring and modelling of biosphere/atmosphere exchange of gases and aerosols in Europe, Environ. Pollut., 133, 403-413, 2005b.

Erisman, J. W., Bleeker, A., Galloway, J., and Sutton, M. S.: Reduced nitrogen in ecology and the environment, Environmental Pollution, 150, 140-149, 2007.

Eugster, W.: Fog Research, Erde, 139, 1-10, 2008.

Falge, E., Reth, S., Bruggemann, N., Butterbach-Bahl, K., Goldberg, V., Oltchev, A., Schaaf, S., Spindler, G., Stiller, B., Queck, R., Kostner, B., and Bernhofer, C.: Comparison of surface energy exchange models with eddy flux data in forest and grassland ecosystems of Germany, Ecol. Model., 188, 174-216, 2005.

Farquhar, G. D., Firth, P. M., Wetselaar, R., and Weir, B.: On the gaseous exchange of ammonia between leaves and the environment - Determination of the ammonia compensation point, Plant Physiol., 66, 710-714, 1980.

Ferm, M.: Atmospheric ammonia and ammonium transport in Europe and critical loads: a review, Nutr. Cycl. Agroecosyst., 51, 5-17, 1998.

Finlayson-Pitts, B. J. and Pitts, J. N.: Chemistry of the upper and lower atmosphere, Academic Press, New York, 1999.

Foken, T., Dlugi, R., and Kramm, G.: On the determination of dry deposition and emission of gaseous compounds at the biosphereatmosphere interface, Meteorol. Z., 4, 91-118, 1995.

Foken, T.: Lufthygienisch-bioklimatische Kennzeichnung des oberen Egertales (Fichtelgebirge bis Karlovy Vary), Bayreuther Forum Ökologie, 1-70, 2003.

Foken, T.: Micrometeorology, 2nd ed., Springer, Berlin, 290 pp., 2008.

Fowler, D. and Duyzer, J. H.: Micrometeorological techniques for the measurement of trace gas exchange, in: Exchange of Trace Gases between Terrestrial Ecosystems and the Atmosphere, edited by: Andreae, M. O. and Schimel, D. S., John Wiley \& Sons Ltd., Chichester, 189-207, 1989.

Fowler, D., Pilegaard, K., Sutton, M. A., Ambus, P., Raivonen, M., Duyzer, J., Simpson, D., Fagerli, H., Fuzzi, S., Schjoerring, J. K., Granier, C., Neftel, A., Isaksen, I. S. A., Laj, P., Maione, M., Monks, P. S., Burkhardt, J., Daemmgen, U., Neirynck, J., Personne, E., Wichink-Kruit, R., Butterbach-Bahl, K., Flechard, C., Tuovinen, J. P., Coyle, M., Gerosa, G., Loubet, B., Altimir, N., Gruenhage, L., Ammann, C., Cieslik, S., Paoletti, E., Mikkelsen, T. N., Ro-Poulsen, H., Cellier, P., Cape, J. N., Horváth, L., Loreto, F., Niinemets, Ü., Palmer, P. I., Rinne, J., Misztal, P., Nemitz, E., Nilsson, D., Pryor, S., Gallagher, M. W., Vesala, T., Skiba, U., Brüggemann, N., Zechmeister-Boltenstern, S., Williams, J., O'Dowd, C., Facchini, M. C., de Leeuw, G., Flossman, A., Chaumerliac, N., and Erisman, J. W.: Atmospheric composition change: Ecosystems-atmosphere interactions, Atmos. Environ., 43, 5193-5267, 2009.

Gallagher, M. W., Beswick, K. M., Duyzer, J., Westrate, H., Choularton, T. W., and Hummelshoj, P.: Measurements of aerosol fluxes to Speulder forest using a micrometeorological technique, Atmos. Environ., 31, 359-373, 1997.

Gallagher, M. W., Nemitz, E., Dorsey, J. R., Fowler, D., Sutton, M. A., Flynn, M., and Duyzer, J.: Measurements and parameterizations of small aerosol deposition velocities to grassland, arable crops, and forest: Influence of surface roughness length on deposition, J. Geophys. Res., 107(D12), 4154-4163, doi:10.1029/2001JD000817, 2002.

Galloway, J. N., Townsend, A. R., Erisman, J. W., Bekunda, M., Cai, Z. C., Freney, J. R., Martinelli, L. A., Seitzinger, S. P., and Sutton, M. A.: Transformation of the nitrogen cycle: Recent trends, questions, and potential solutions, Science, 320, 889892, 2008.

Garratt, J. R.: Flux profile relations above tall vegetation, Q. J. Roy. Meteorol. Soc., 104, 199-211, 1978.

Garratt, J. R.: The Atmospheric Boundary Layer, Cambridge University Press, 1992.

Hall, B., Claiborn, C., and Baldocchi, D.: Measurement and modeling of the dry deposition of peroxides, Atmos. Environ., 33, 577-589, 1999.

Held, A., Wrzesinsky, T., Mangold, A., Gerchau, J., and Klemm, O.: Atmospheric phase distribution of oxidized and reduced nitrogen at a forest ecosystem research site, Chemosphere, 48, 697-706, 2002.

Held, A. and Klemm, O.: Direct measurement of turbulent particle exchange with a twin CPC eddy covariance system, Atmos. Environ., 40, S92-S102, 2006.

Hertel, O., Skjoth, C. A., Lofstrom, P., Geels, C., Frohn, L. M., Ellermann, T., and Madsen, P. V.: Modelling nitrogen deposition on a local scale - A review of the current state of the art, Environ. Chem., 3, 317-337, 2006.

Högström, U., Bergstrom, H., Smedman, A. S., Halldin, S., and Lindroth, A.: Turbulent exchange above a pine forest: 1 . fluxes and gradients, Bound.-Lay. Meteorol., 49, 197-217, 1989.

Hovmand, M. F. and Andersen, H. V.: Nine years of measurements of atmospheric nitrogen and sulphur deposition to Danish forest, Water Air Soil Pollut., 85, 2205-2210, 1995.

Huebert, B. J. and Robert, C. H.: The dry deposition of nitric-acid to grass, J. Geophys. Res., 90, 2085-2090, 1985.

Huebert, B. J., Luke, W. T., Delany, A. C., and Brost, R. A.: Measurements of concentrations and dry surface fluxes of atmospheric nitrates in the presence of ammonia, J. Geophys. Res., 93, 7127-7136, 1988.

Klemm, O. and Lange, H.: Trends of air pollution in the Fichtelgebirge Mountains, Bavaria, Environ. Sci. Pollut. R., 6, 193-199, 1999.

Klemm, O., Held, A., Forkel, R., Gasche, R., Kanter, H. J., Rappengluck, B., Steinbrecher, R., Muller, K., Plewka, A., Cojocariu, C., Kreuzwieser, J., Valverde-Canossa, J., Schuster, G., Moortgat, G. K., Graus, M., and Hansel, A.: Experiments on forest/atmosphere exchange: Climatology and fluxes during two summer campaigns in NE Bavaria, Atmos. Environ., 40, S3-S20, 2006.

Klemm, O. and Wrzesinsky, T.: Fog deposition fluxes of water and ions to a mountainous site in Central Europe, Tellus Series BChemical and Physical Meteorology, 59, 705-714, 2007.

Kramm, G. and Dlugi, R.: Modeling of the vertical fluxes of nitricacid, ammonia, and ammonium-nitrate, J. Atmos. Chem., 18, 319-357, 1994.

Krupa, S. V.: Effects of atmospheric ammonia $\left(\mathrm{NH}_{3}\right)$ on terrestrial vegetation: a review, Environ. Pollut., 124, 179-221, 2003.

Lovett, G. M. and Lindberg, S. E.: Dry deposition and canopy exchange in a mixed oak forest as determined by analysis of throughfall, J. Appl. Ecol., 21, 1013-1027, 1984.

Lovett, G. M., Nolan, S. S., Driscoll, C. T., and Fahey, T. J.: Fac- 
tors regulating throughfall flux in a new New-Hampshire forested landscape, Can. J. For. Res.-Rev. Can. Rech. For., 26, 21342144, 1996.

Mayer, J. C.: Transport Processes of Reactive Trace Gases in the Atmospheric Boundary Layer, $\mathrm{PhD}$, Faculty of biology, chemistry and geosciences, University of Bayreuth, Bayreuth, 119 pp., 2008.

Meng, Z. and Seinfeld, J. H.: Time scales to achieve atmospheric gas-aerosol equilibrium for volatile species, Atmos. Environ., 30, 2889-2900, 1996.

Mozurkewich, M.: The dissociation constant of ammonium nitrate and its dependence on temperature, relative humidity and particle size, Atmos. Environ. Part A. General Topics, 27, 261-270, 1993.

Nagel, H. D., Becker, R., Eitner, H., Hübener, P., Kunze, F., Schlutow, A., Schütze, G., and Weigelt-Kirchner, R.: Critical Loads für Säure und eutrophierenden Stickstoff, Umweltbundesamt, $172,2004$.

Nemitz, E. and Sutton, M. A.: Gas-particle interactions above a Dutch heathland: III. Modelling the influence of the $\mathrm{NH}_{3}$ $\mathrm{HNO}_{3}-\mathrm{NH}_{4} \mathrm{NO}_{3}$ equilibrium on size-segregated particle fluxes, Atmos. Chem. Phys., 4, 1025-1045, doi:10.5194/acp-4-10252004, 2004.

Nemitz, E., Sutton, M. A., Wyers, G. P., and Jongejan, P. A. C.: Gas-particle interactions above a Dutch heathland: I. Surface exchange fluxes of $\mathrm{NH}_{3}, \mathrm{SO}_{2}, \mathrm{HNO}_{3}$ and $\mathrm{HCl}$, Atmos. Chem. Phys., 4, 989-1005, doi:10.5194/acp-4-989-2004, 2004a.

Nemitz, E., Sutton, M. A., Wyers, G. P., Otjes, R. P., Mennen, M. G., van Putten, E. M., and Gallagher, M. W.: Gas-particle interactions above a Dutch heathland: II. Concentrations and surface exchange fluxes of atmospheric particles, Atmos. Chem. Phys., 4, 1007-1024, doi:10.5194/acp-4-1007-2004, 2004 b.

Peters, K. and Eiden, R.: Modelling the dry deposition velocity of aerosol particles to a spruce forest, Atmos. Environ. Part A. General Topics, 26, 2555-2564, 1992.

Rebmann, C., Gockede, M., Foken, T., Aubinet, M., Aurela, M., Berbigier, P., Bernhofer, C., Buchmann, N., Carrara, A., Cescatti, A., Ceulemans, R., Clement, R., Elbers, J. A., Granier, A., Grunwald, T., Guyon, D., Havrankova, K., Heinesch, B., Knohl, A., Laurila, T., Longdoz, B., Marcolla, B., Markkanen, T., Miglietta, F., Moncrieff, J., Montagnani, L., Moors, E., Nardino, M., Ourcival, J. M., Rambal, S., Rannik, U., Rotenberg, E., Sedlak, P., Unterhuber, G., Vesala, T., and Yakir, D.: Quality analysis applied on eddy covariance measurements at complex forest sites using footprint modelling, Theor. Appl. Climatol., 80, 121-141, 2005.

Rothe, A., Huber, C., Kreutzer, K., and Weis, W.: Deposition and soil leaching in stands of Norway spruce and European Beech: Results from the Hoglwald research in comparison with other European case studies, Plant and Soil, 240, 33-45, 2002.

Seinfeld, J. H. and Pandis, S. N.: Atmospheric chemistry and physics: From air pollution to climate change, Wiley, New York, 1998.

Sievering, H., Enders, G., Kins, L., Kramm, G., Ruoss, K., Roider, G., Zelger, M., Anderson, L., and Dlugi, R.: Nitric-acid, particulate nitrate and ammonium profiles at the Bayerischer-Wald Evidence for large deposition rates of total nitrate, Atmos. Environ., 28, 311-315, 1994.

Simpson, I. J., Thurtell, G. W., Neumann, H. H., Den Hartog, G., and Edwards, G. C.: The validity of similarity theory in the roughness sublayer above forests, Bound.-Lay. Meteorol., 87, 69-99, 1998.

Staudt, K. and Foken, T.: Documentation of reference data for the experimental areas of the Bayreuth Center for Ecology and Environmental Research (BayCEER) at the Waldstein site, Dep. Micromet., University of Bayreuth, 2007.

Stelson, A. W. and Seinfeld, J. H.: Relative-humidity and temperature-dependence of the ammonium-nitrate dissociationconstant, Atmos. Environ., 16, 983-992, 1982.

Sutton, M. A., Nemitz, E., Milford, C., Fowler, D., Moreno, J., San Jose, R., Wyers, G. P., Otjes, R. P., Harrison, R., Husted, S., and Schjoerring, J. K.: Micrometeorological measurements of net ammonia fluxes over oilseed rape during two vegetation periods, Agricultural and Forest Meteorology, 105, 351-369, 2000.

Sutton, M. A., Nemitz, E., Erisman, J. W., Beier, C., Bahl, K. B., Cellier, P., de Vries, W., Cotrufo, F., Skiba, U., Di Marco, C., Jones, S., Laville, P., Soussana, J. F., Loubet, B., Twigg, M., Famulari, D., Whitehead, J., Gallagher, M. W., Neftel, A., Flechard, C. R., Herrmann, B., Calanca, P. L., Schjoerring, J. K., Daemmgen, U., Horvath, L., Tang, Y. S., Emmett, B. A., Tietema, A., Penuelas, J., Kesik, M., Brueggemann, N., Pilegaard, K., Vesala, T., Campbell, C. L., Olesen, J. E., Dragosits, U., Theobald, M. R., Levy, P., Mobbs, D. C., Milne, R., Viovy, N., Vuichard, N., Smith, J. U., Smith, P., Bergamaschi, P., Fowler, D., and Reis, S.: Challenges in quantifying biosphere-atmosphere exchange of nitrogen species, Environ. Pollut., 150, 125-139, 2007.

Thom, A. S., Stewart, J. B., Oliver, H. R., and Gash, J. H. C.: Comparison of aerodynamic and energy budget estimates of fluxes over a pine forest, Q. J. Roy. Meteorol. Soc., 101, 93-105, 1975.

Thomas, C. and Foken, T.: Flux contribution of coherent structures and its implications for the exchange of energy and matter in a tall spruce canopy, Bound.-Lay. Meteorol., 123, 317-337, 2007.

Thomas, R.: Measurement of speciated aerosol fluxes, PhD, Faculty of Engineering and Physical Science, University of Manchester, Manchester, 296 pp., 2007.

Thomas, R. M., Trebs, I., Otjes, R., Jongejan, P. A. C., Brink, H. t., Phillips, G., Kortner, M., Meixner, F. X., and Nemitz, E.: An automated analyzer to measure surface-atmosphere exchange fluxes of water soluble inorganic aerosol compounds and reactive trace gases, Environ. Sci. Technol., 43, 1412-1418, doi:10.1021/es8019403, 2009.

Trebs, I., Meixner, F. X., Slanina, J., Otjes, R., Jongejan, P., and Andreae, M. O.: Real-time measurements of ammonia, acidic trace gases and water-soluble inorganic aerosol species at a rural site in the Amazon Basin, Atmos. Chem. Phys., 4, 967-987, doi:10.5194/acp-4-967-2004, 2004.

Trebs, I., Lara, L. L., Zeri, L. M. M., Gatti, L. V., Artaxo, P., Dlugi, R., Slanina, J., Andreae, M. O., and Meixner, F. X.: Dry and wet deposition of inorganic nitrogen compounds to a tropical pasture site (Rondnia, Brazil), Atmos. Chem. Phys., 6, 447-469, doi:10.5194/acp-6-447-2006, 2006.

Tsokankunku, A., Zhu, Z., Meixner, F. X., Foken, T., and Andreae, M. O.: Eddy covariance fluxes of the $\mathrm{NO}-\mathrm{NO}_{2}-\mathrm{O}_{3}$ triad above a spruce forest canopy in south-eastern Germany, EGU General Assembly, Vienna, 19-24 April 2009.

Valverde-Canossa, J., Ganzeveld, L., Rappengluck, B., Steinbrecher, R., Klemm, O., Schuster, G., and Moortgat, G. K.: First measurements of $\mathrm{H}_{2} \mathrm{O}_{2}$ and organic peroxides surface fluxes by 
the relaxed eddy-accumulation technique, Atmos. Environ., 40, S55-S67, 2006.

van Breemen, N. and van Dijk, H. F. G.: Ecosystem effects of atmospheric deposition of nitrogen in The Netherlands, Environ. Pollut., 54, 249-274, 1988.

Walcek, C. J.: A theoretical estimate of $\mathrm{O}_{3}$ and $\mathrm{H}_{2} \mathrm{O}_{2}$ dry deposition over the northeast United-States, Atmos. Environ., 21, 2649-2659, 1987.

Wesely, M. L. and Hicks, B. B.: A review of the current status of knowledge on dry deposition, Atmos. Environ., 34, 2261-2282, 2000.

Wexler, A. S. and Seinfeld, J. H.: Analysis of aerosol ammoniumnitrate - Departures from equilibrium during SCAQS, Atmospheric Environment Part A-General Topics, 26, 579-591, 1992.

Wichura, B., Ruppert, J., Delany, A. C., Buchmann, N., and Foken, T.: Structure of carbon dioxide exchange processes above a spruce forest, in: Biogeochemistry of Forested Catchments in a Changing Environment: an German Case Study, Ecological Studies : Analysis and Synthesis, Springer-Verlag Berlin, Berlin, 161-176, 2004.
Wolff, V., Trebs, I., Ammann, C., and Meixner, F. X.: Aerodynamic gradient measurements of the $\mathrm{NH}_{3}-\mathrm{HNO}_{3}-\mathrm{NH}_{4} \mathrm{NO}_{3}$ triad using a wet chemical instrument: an analysis of precision requirements and flux errors, Atmos. Meas. Tech., 3, 187-208, doi:10.5194/amt-3-187-2010, 2010.

Wrzesinsky, T. and Klemm, O.: Summertime fog chemistry at a mountainous site in central Europe, Atmos. Environ., 34, 14871496, 2000.

Zimmermann, F., Plessow, K., Queck, R., Bernhofer, C., and Matschullat, J.: Atmospheric N- and S-fluxes to a spruce forest Comparison of inferential modelling and the throughfall method, Atmos. Environ., 40, 4782-4796, 2006.

Zimmermann, L. and Zimmermann, F.: Fog deposition to Norway Spruce stands at high-elevation sites in the Eastern Erzgebirge (Germany), J. Hydrol., 256, 166-175, 2002. 